\begin{abstract}
We survey the microfoundations, empirical evidence and estimation issues underlying the aggregate matching function. Several microeconomic matching mechanisms have been suggested in the literature with some successes but none is generally accepted as superior to all others. Instead, an aggregate matching function with hires as a function of vacancies and unemployment has been successfully estimated for several countries. The Cobb-Douglas restrictions with constant returns to scale perform well. Recent work has utilized disaggregated data to go beyond aggregate estimates, with many refinements and suggestions for future research.
\end{abstract}

This paper was produced as part of the Centre's Technology and Growth Programme 


\title{
Looking Into the Black Box: A Survey of the Matching
}

Function

\author{
Barbara Petrongolo and Christopher A. Pissarides
}


Published by

Centre for Economic Performance

London School of Economics and Political Science

Houghton Street

London WC2A 2AE

(C) Barbara Petrongolo and Christopher A. Pissarides, submitted February 2000

ISBN 0753014092

Individual copy price: $£ 5$ 


\section{Looking Into the Black Box: A Survey of the Matching Function}

\section{Barbara Petrongolo and Christopher A. Pissarides}

1. Introduction 2

2. The Key Idea and Some Evidence 3

3. Microfoundations $\quad 7$

$\begin{array}{lll}3.1 & \text { Mismatch } & 7\end{array}$

3.2 Coordination failures 9

3.3 Worker heterogeneity: search intensity and reservation wages 11

$\begin{array}{lll}3.4 & \text { Ranking } & 13\end{array}$

$\begin{array}{ll}3.5 & \text { Stock-flow matching } \\ 3.6 & 14\end{array}$

$\begin{array}{lll}3.6 & \text { Aggregation over distinct markets } & 17\end{array}$

4. Empirical Methods and Findings 18

$\begin{array}{lll}4.1 & \text { Beveridge curves } & 19\end{array}$

$\begin{array}{lll}4.2 & \text { Aggregate studies } & 21\end{array}$

4.3 Sectoral studies $\quad 26$

$\begin{array}{lll}4.4 & \text { Micro studies } & 27\end{array}$

5. Search On the Job and Out of the Labor Force 29

6. Aggregation Issues $\quad 34$

$\begin{array}{lll}6.1 & \text { Time aggregation } & 34\end{array}$

$\begin{array}{lll}6.2 & \text { Spatial aggregation } & 38\end{array}$

$\begin{array}{ll}\text { 7. Conclusions } & 40\end{array}$

References $\quad 41$

8. Appendix: Some History 52

$\begin{array}{ll}\text { Tables } & 57\end{array}$

The Centre for Economic Performance is financed by the Economic and Social Research Council. 


\section{Ackowledgments}

We are grateful to Alan Manning, Tony Venables and an anonymous referee for useful comments. Funding for this project was provided by the Centre for Economic Performance and the Spanish Ministry of Education (Grant No PB97-0091).

Barbara Petrongolo is at the Centre for Economic Performance, London School of Economics and the Universidad Carlos III de Madrid. Christopher A. Pissarides is a Programme Director at the Centre for Economic Performance and a Professor of Economics at the London School of Economics. 


\title{
Looking Into the Black Box: A Survey of the Matching Function
}

\author{
Barbara Petrongolo \\ University Carlos III, Madrid \\ Centre for E conomic Performance and CEPR \\ Christopher A. Pissarides \\ Centre for E conomic Performance \\ London School of Economics and CEPR
}

September 15, 2000 


\section{Introduction}

"Frictions" have made important inroads in modern macroeconomics. In the labor market they are used to explain the existence of unemployment and (sometimes) wage inequality. In business cycle models they are used to explain the ampli..cation of the response of employment to aggregate shocks. In coordination-failures models they are used to justify the dependence of the strategy of one agent on that of another. In monetary models they are used to explain the existence of money. ${ }^{1}$ In the majority of cases, the modeling tool used to capture the infuence of frictions on equilibrium outcomes is the aggregate matching function. This paper surveys recent work on the existence and stability of the aggregate matching function, with emphasis on microfoundations and empirical ..ndings.

The attraction of the matching function is that it enables the modeling of frictions in otherwise conventional models, with the minimum of added complexity. Frictions derive from information imperfections about potential trading partners, heterogeneities, the absence of perfect insurance markets, slow mobility, congestion from large numbers, and other similar factors. Modeling each one of these explicitly would introduce intractable complexities in macroeconomic models. The matching function captures their exects on equilibrium outcomes in terms of a small number of variables, usually without explicit reference to the source of the friction.

Frictions also introduce monopoly rents in competitive markets, which in $\ddagger u$ ence behavior. The matching function has been used to study their implications for wage and price determination. ${ }^{2}$ The Appendix traces the history of frictions in economic modeling, leading up to the recent generation of equilibrium models with matching frictions. It argues that although the matching function was not "discovered" by the recent vintage of models, in the sense that the idea (and sometimes functional form) were present in earlier models, it was not until the late 1970s that it explicitly appeared in equilibrium models and was given a new and far more important role in the characterization of equilibrium than had previously been the case. In uential in this respect were equilibrium models of wage and em-

\footnotetext{
${ }^{1}$ R epresentative references include $P$ issarides (2000) and M ortensen and P issarides (1999b) on the labor market, M ontgomery (1991) and A cemoglu and Shimer (2000) on wage inequality, M erz (1985) and Andolfatto (1986) on business cycles, Cooper and J ohn (1988) and Diamond (1982a) on coordination failures, and Diamond (1984) and Kiyotaki and Wright (1989) on monetary exchange.

${ }^{2}$ See, for example, Diamond (1982b) and the labor market references in the preceding footnote.
} 
ployment determination (Diamond, 1982a,b, Mortensen, 1982a,b, and Pissarides, 1984,1985).

Virtually all the work that we survey focuses on the labor market. This is partly explained by the fact that frictions are likely to be more important in the labor market than in other markets. But it also has to do with the fact that in labor markets there are data sets that can be used to estimate and test the matching function. A lot of the recent interest in the matching function stems from the realization that modern labor markets are characterized by well-documented, large $\ddagger$ ows of jobs and workers between activity and inactivity ${ }^{3}$ The matching of workers to new jobs is one half of the explanation for these ‡ows. Its outcome, in conjunction with the outcome of the process that separates workers from jobs, is often shown graphically in vacancy-unemployment space by the "Beveridge curve." ${ }^{4}$ Estimated Beveridge curves can shed light on the nature of the aggregate matching function and we discuss some below. Most of the evidence that we discuss, however, is in studies that estimate a matching function directly, either at the aggregate or the sectoral level.

In section 2 we discuss the main ideas behind the matching function and we give some pertinent evidence. We then take a look at the theoretical foundations of the matching function and discuss some of the more important variables that are likely to be inłuential in empirical work (section 3). Section 4 discusses empirical results in the context of the methods most frequently adopted in the estimation of the matching function. Section 5 deals with the conceptual and measurement issues due to search on the job and to the transitions of workers from out of the labor force to employment. A ggregation problems across time and space are discussed in section 6. The main conclusions are brought together in section 7. The A ppendix gives a brief historical overview of the literature on the role of labor market frictions, leading to the birth of the matching function.

\section{The Key Idea and Some Evidence}

The matching function summarizes a trading technology between agents who place advertisements, read newspapers and trade magazines, go to employment agencies

\footnotetext{
${ }^{3}$ See Davis et al. (1996) on the importance of job ¥ows and Blanchard and Diamond (1990a) on the importance of worker łows in the United States, and Burda and Wyplosz (1994) and Contini et al. (1995) on the importance of łows in Europe.

${ }^{4}$ See Pissarides (2000, chapter 1), B lanchard and Diamond (1989) and the many other references listed in the notes on the literature to chapters 1 and 2 of P issarides (2000).
} 
and mobilize local networks that eventually bring them together into productive matches. The key idea is that this complicated exchange process is summarized by a well-behaved function that gives the number of jobs formed at any moment in time in terms of the number of workers looking for jobs, the number of ..rms looking for workers and a small number of other variables.

The matching function is a modeling device that occupies the same place in the macroeconomist's tool kit as other aggregate functions, such as the production function and the demand for money function. Like the other aggregate functions its usefulness depends on its empirical viability and on how successful it is in capturing the key implications of the heterogeneities and frictions in macro models. In this survey we will focus on the microfoundations underlying the matching function and on its empirical success but we will not discuss its modeling exectiveness.

The simplest form of the matching function is

$$
M=m(U ; V) \text {; }
$$

where $\mathrm{M}$ is the number of jobs formed during a given time interval, $\mathrm{U}$ is the number of unemployed workers looking for work and $\mathrm{V}$ the number of vacant jobs. The matching function is assumed increasing in both its arguments and concave and usually homogeneous of degree 1 . Testing for homogeneity, or constant returns to scale, has been one of the preoccupations of the empirical literature. Other restrictions usually imposed are $\mathrm{m}(0 ; \mathrm{V})=\mathrm{m}(\mathrm{U} ; 0)=0$ and in discrete-time models where $\mathrm{M}$ is the $\neq$ ow of matches during an elementary period and $\mathrm{U}$ and $\mathrm{V}$ are the stocks at the beginning of the period, $\mathrm{m}(\mathrm{U} ; \mathrm{V}) \cdot \min (\mathrm{U} ; \mathrm{V}):$ In continuous time models, $M$ is the instantaneous rate of job matching and $U$ and $V$ the instantaneous stocks of unemployment and vacancies. In the absence of frictions, $M=\min (U ; V)$ in discrete-time formulations and $M$ ! 1 in continuous-time models. Under constant returns to scale, $\mathrm{M} ; \mathrm{U}$ and $\mathrm{V}$ are usually normalized by the labor force size, and denoted by lower-case letters.

On average an unemployed worker ..nds a job during a period of unit length with probability $m(U ; V)=U$. Similarly, a vacant job is ...led with probability $m(U ; V)=V$. In a stationary environment, the inverse of each probability is the mean duration of unemployment and vacancies respectively. Of course, if workers and jobs are heterogeneous, the transition probabilities (or hazard rates) will dixer across the labor market, as will the mean durations. The aggregate matching function is a useful device for introducing heterogeneities across workers, by making the probability $\mathrm{m}(\mathrm{U} ; \mathrm{V})=\mathrm{U}$ depend on individual characteristics. This 
has been a theme of the empirical literature which estimates hazard functions for individual workers.

The dependence of the mean transition rates on the number of workers and ..rms engaged in search is an externality that has played an important role in the analysis of the ec ciency of search equilibrium. The average time that it takes a ..rm to ..nd a worker depends on what searching workers do before they meet the ..rm. Similarly, the probability that an unemployed worker ..nds a job depends on what hiring ..rms do, for example on whether they advertise or not and where they advertise. Generally, search equilibrium is inec cient because when ..rms and workers meet the costs of their search, which infuence the transition probabilities, are sunk.

The returns to scale in the matching function play an important role in models with endogenous search exort. If there are increasing returns to matching, as the authors of some early models assumed (Diamond, 1982a, Howitt and McAxee, 1987) then there could be more than one equilibrium because of the complementarity between the search inputs of ..rms and workers: in one equilibrium ..rms and workers put more resources into search, pushing up the returns from search available to the other side, which justify the bigger inputs; in another they put less exort into search with lower returns from search, lower matching rate and higher unemployment. Increasing returns to scale can support the high and low activity equilibria even when there are increasing marginal costs to search exort, whereas constant returns cannot (although the complementarity between the actions of ..rms and workers is still present).

Evidence on the key matching-function idea comes from four sources. The ..rst one uses aggregate data on stocks of unemployment and vacancies and estimates an equilibrium relation, the Beveridge (or UV) curve. The second uses aggregate data on fows out of unemployment and estimates the aggregate matching function, either for the whole economy or for a particular sector (usually manufacturing). The third uses data on local labor markets, which can be either a time-series or a panel, and estimates the matching function for each. The fourth uses data on individual transitions and estimates hazard functions for unemployed workers. We discuss each approach in some detail in subsequent sections. Here we summarize the main implications of the empirical research for the simple matching function in (2.1).

The B everidge curve is an equilibrium relation that equates $\ddagger$ ows in with $\ddagger$ ows out of unemployment. In vacancy-unemployment space it slopes downward if the outłow from unemployment is given by the matching function in (2.1). Estimated 
B everidge curves slope downwards but shift over time, especially in cases where there have been secular increases in unemployment, as in most E uropean countries since the mid 1970s. So the matching function in (2.1) is not contradicted by the B everidge-curve evidence; but this evidence is indirect, it is consistent with other mechanisms, and points to other variables that inłuence job matching too.

Direct estimates of the matching function give better information about the properties of (2.1). Table 1 summarizes the speci..cations adopted by aggregate studies. Most studies that estimate aggregate functions ..nd that a log-linear approximation to (2.1) ..ts the data well. When data for the whole economy are used the estimated functions satisfy constant returns to scale but some estimates with manufacturing data show mildly increasing returns. The estimated elasticities with respect to unemployment and vacancies vary, depending on whether the dependent variable is the out $\ddagger$ ow from unemployment or the $¥$ ow from unemployment to employment. When the dependent variable is the total out $\neq$ ow from unemployment the estimated elasticity on unemployment is about 0.7 and the elasticity on vacancies 0.3 . Precise data on unemployment-to-employment transitions are rarely available but when an approximation for the matching rate is used the elasticity on unemployment drops, although not by much when other fows into employment are ignored. A plausible range for the empirical elasticity of unemployment is 0.5 to 0.7 . There are good reasons for the drop in the elasticity estimates when łows from unemployment to non-employment are ignored, that we discuss when we look at the estimates in more detail.

The aggregate estimates also ..nd that there are other variables that in $\ddagger$ uence matching in a systematic way. Disaggregate estimates, summarized in Table 2 , have not contradicted the aggregate estimates but concentrated instead on ...nding out what are those other variables and whether aggregation introduces biases that can be estimated. With the number of estimates growing signi..cantly in recent years, it is natural that there are estimates of both increasing and decreasing returns to scale. But such divergencies from constant returns are only mild and rare. The stylized fact that emerges from the empirical literature is that there is a stable aggregate matching function of a few variables that satis..es the Cobb-Douglas restrictions with constant returns to scale in vacancies and unemployment.

Table 3 summarizes the results of studies that tested for constant returns. The estimates of Burda and Wyplosz (1994) for some European countries show diminishing returns to scale and those of Blanchard and Diamond (1990b) and Warren (1996) for US manufacturing and Yashiv (2000) for Israel show increasing returns. All other estimates, however, support constant returns. 


\section{Microfoundations}

What are the reasons for the existence of a well-behaved matching function and what are the other variables that in $¥$ uence the matching rate? In order to answer these questions we need to look at the microfoundations behind the aggregate matching function. The literature has done that; but although there are several microeconomic models that can be used to justify the existence of an aggregate matching function, none commands universal support and none convincingly says why the aggregate matching function should be of the Cobb-Douglas form. The literature has had more success, however, in suggesting what should be the other variables that in uence the matching rate.

The other variables can be classi...ed into two groups. The ..rst group includes everything that individuals do during search, such as choosing how many applications to make, changing their advertising methods etc. The second includes shifts unrelated to individual search decisions. We take up the second group ..rst. M ost of the theoretical work on matching functions studies individual behavior and is discussed in the subsections that follow.

\subsection{M ismatch}

The shifts in the matching function that are unrelated to search decisions are due to technological advances in matching and to aggregation issues. Technological advances include reforms such as the computerization of employment o\$ ces, job advertising on the internet, an increase in the resources that governments put into subsidized matching, and other similar changes. Although changes of this type have been observed recently in most industrial countries (see OECD, 1994, ch. $6,1999)$ and they have infuenced the matching process to the extent that the OECD recommends them to its members as the most cost-exective "active" labor market policies, they have attracted little formal theoretical or empirical work.

A ggregation issues have attracted more attention from labor economists, often disguised under the label "mismatch". Mismatch is an empirical concept that measures the degree of heterogeneity in the labor market across a number of dimensions, usually restricted to skills, industrial sector and location. Large dixerences in skills among ..rms would lengthen the time that it takes to match a given group of workers to a given group of ..rms, as agents search for a good match among the heterogeneous group. Industrial sector matters in matching because of industry-speci..c skills that may not be picked up by generally available measures of skills. Finally, location inłuences matching because of imperfect labor mobil- 
ity. Although the term "mismatch" has been used in the literature to describe all three dimensions (see Layard et al., 1991), the term "imbalance" in numbers in the local market has been used before to describe dixerences in the distribution of locations (see e.g. Holt, 1970b) and is a useful way of distinguishing between skill mismatch and dixerences in location.

If mismatch and imbalance in an economy were identically zero in all their dimensions, the matching function would not exist and jobs and workers would match instantaneously. It is because of the existence of some mismatch that meetings take place only after a search and application process. If there is an exogenous rise in mismatch, the rate of job matches at given inputs must fall, implying a shift in the aggregate matching function.

Of course, if empirically mismatch changes frequently in ways that cannot be accurately measured, the usefulness of the concept of the matching function is reduced. But this requirement is not dixerent from the one on other aggregate functions in the macroeconomist's tool kit. Some of the early controversies in production theory (like the capital controversy of the two Cambridges) were about the question whether factors of production could be aggregated into two or three composites that enter a single-valued dixerentiable production function. W hether in practice aggregation problems are serious enough to question the usefulness of the matching function is an empirical question. The available evidence does not support serious aggregation problems that cannot be dealt with empirically.

In the empirical literature, mismatch, or imbalance, bears some relationship to the frequently discussed "sectoral shifts hypothesis", and to the older view of "structural" unemployment, which was thought to be unemployment arising from fast structural change in the economy as a whole. For example, it has been argued that the oil, technology and other supply shocks of the 1970s and 1980s increased the speed with which unemployed workers needed to adapt to the changing requirements of employers. This led to increased mismatch between the skills possessed by workers and the skill requirements of employers, which increased the duration of unemployment (and hence the stock of unemployment) at given vacancies.

Lilien (1982) argues that imbalance in the distribution of jobs and workers changes over the business cycle, to the extent that it can adequately explain the observed fuctuations in aggregate employment. Although he ..nds that his sectoral shifts hypothesis has some success in explaining US employment data, his ..ndings have been exectively criticized by Abraham and K atz (1986) and Blanchard and Diamond (1989). Their critique points to the fact that the observed 
positive correlation between the dispersion of employment growth and the unemployment rate can be either produced by sectoral shifts or by aggregate demand fuctuations. Information on job vacancies allows one to distinguish between the two explanations. The strong negative correlation between unemployment and vacancies supports an aggregate-demand interpretation of US employment ‡uctuations rather than one based on sectoral shifts. Similar conclusions can be reached from the observation that job creation and job destruction rates across sectors are negatively correlated over the cycle (see Davis et al., 1996).

Layard et al. (1991, chapter 6) follow a dixerent approach and measure mismatch by the variance of sectoral unemployment rates. They show, however, that their measure of mismatch cannot account for the shifts in the aggregate matching function or the variance in UK unemployment. More recently, Manacorda and Petrongolo (1999) propose a measure of skill mismatch that makes use of information about the demand and the supply of skills, represented respectively by productivity parameters and labor force shares. This leads them to the conclusion that the unbalanced evolution of the demand and the supply of skills can explain some of the rise in unemployment in Britain, and hence some of the observed shifts in the matching function, but still not all.

On balance, neither the sectoral shifts hypothesis nor mismatch has had much success in accounting for a large fraction of fuctuations in employment or for the secular rise in unemployment in some countries. So although empirical mismatch variables can account for some of the shifts in the aggregate matching function, we should look elsewhere for the main shift variables. But some authors (see for example Entorf, 1998) argue that the measurement of mismatch in aggregate studies of matching functions still suxers from many problems, and may be able to account for more of the unexplained variance in matchings than currently found in the literature.

If aggregation problems are not an issue, what can account for the matching function and what else can shift it?

\subsection{Coordination failures}

The ..rst matching function owes its origins to a well-known problem analyzed by probability theorists, that of randomly placing balls in urns (Butters, 1977, Hall, 1979, Pissarides, 1979, Lang, 1991, M ontgomery, 1991, Blanchard and Diamond, 1994). Firms play the role of urns and workers the role of balls. An urn becomes "productive" when it has a ball in it. But even if there was exactly the same 
number of urns and balls, it is well-known that a random placing of the balls in the urns will not match all the pairs exactly, because of a coordination failure by those placing the balls in the urns. Some urns will end up with more than one ball and some with none. In the context of the labor market, if only one worker could occupy each job, an uncoordinated application process by workers will lead to overcrowding in some jobs and no applications to others. The imperfection that leads to unemployment here is the lack of information about other workers' actions, though simple extensions could enrich the source of frictions.

In the simplest version of this process $U$ workers know exactly the location of $\mathrm{V}$ job vacancies and send one application each. If a vacancy receives one or more applications it selects an applicant at random and forms a match. The other applicants are returned to the pool of unemployed workers to apply again. The matching function is derived by writing down an expression for the number of vacancies that do not receive any applications. Given that each vacancy receives a worker's application with probability $1=V$; and there are $U$ applicants, there is a probability $(1 ; 1=V)^{\cup}$ that a given vacancy will not receive any applications at all. Therefore, the number of matches that take place at each application round is

$$
M=V^{h} 1 ;(1 ; 1=V)^{u^{i}} \text { : }
$$

For a large $\mathrm{V}$ a good approximation to $(1 ; 1=V)^{\mathrm{U}}$ is the exponential $\mathrm{e}^{\mathrm{U}} \mathrm{U}=\mathrm{V}$; giving the matching function

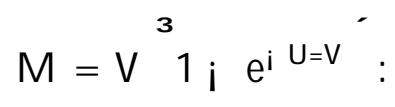

This matching function clearly satis. es the properties satis..ed by the general function in (2.1), and in addition it satis..es constant returns to scale. It is, however, too naive to be empirically a good approximation to matching in real labor markets. For example, it implies an implausible combination of levels and durations of unemployment. If the level of unemployment and vacancies is the same, the mean duration of unemployment is 1:58 periods and if the level of unemployment is three times as high as that of vacancies, mean duration is 3:16: In actual labor markets duration would rise by more than the function (3.2) implies when the level of unemployment is higher.

The introduction of small additional frictions to the urn-ball framework can enrich the matching function considerably. We consider three related extensions. In the ..rst, workers do not know the ..rms with the vacancies and choose at random one ..rm to apply. Then the probability that a vacancy receives no applications is $(1$ i $1 \neq N+V))^{U}$; where $\mathrm{N}$ is the level of employment. If in addition 
the labor force size is $\mathrm{L}, \mathrm{N}=\mathrm{L} i \underset{3}{\mathrm{U}}$; the matching function becomes,

$$
M=V 1 i_{i} e^{i U=(L i U+V)} \text { : }
$$

This matching function exhibits increasing returns to scale in $U$ and $V$ and may even fail the assumption of diminishing returns to unemployment, though this would require more vacancies than employment. But it satis..es constant returns to L; U and V; so it avoids the counter-factual implication that larger countries should have lower equilibrium unemployment rates than otherwise identical smaller countries.

In the second extension, not all workers are suitable for the vacancies available but the worker does not know which vacancies are suitable. Let $\mathrm{K}$ be the fraction of workers who are suitable employees for a randomly picked vacancy. The probability that a vacancy will not be visited by a worker is still $1=V$ but only $\mathrm{K} U$ workers can now take the job. The matching function therefore generalizes to

$$
M=V 1 ; e^{i K U=V} \text {; }
$$

with the inverse of $K$ standing as an index of mismatch between the available jobs and workers.

Our third extension gives a similar matching function but the new parameter is associated with search intensity. Each period a fraction $1_{i}$ s of the unemployed do not apply for a job. This fraction rotates, so each unemployed worker misses one application round out of every $1 \neq 1 \mathrm{i}$ s) rounds. Then, the probability that a given vacancy receives no applications during a given application round is $(1 ; 1=V)^{\text {sU }}$; giving the matching function

$$
M=V^{3} 1 \text { i } e^{\text {isU }=V^{\prime}} \text { : }
$$

Both (3.4) and (3.5) satisfy all the properties of (2.1) for given $\mathrm{K}$ and $\mathrm{s}$; but in addition open up the possibility of modeling mismatch and the frequency of applications, and so bringing the simple form (3.2) closer to the data. The mean duration of unemployment for these functions is again $U \neq \mathrm{M}$ and so more imbalance or a lower application frequency gives the longer mean durations for given vacancy-to-unemployment ratio that the data suggest. We take up the question of what might determine s next.

\subsection{Worker heterogeneity: search intensity and reservation wages}

The hazard rates (or unemployment durations) derived in the preceding section were for "representative" individuals, without explicit dependence on individual 
characteristics. Yet, in empirical estimates, it is found that individual characteristics play an important role in accounting for dixerences in hazard rates across individuals. In this sub-section and the next, we suggest two ways of introducing the infuence of individual characteristics in the matching technology and show what this does to the aggregate matching function.

Worker heterogeneity is most conveniently introduced into the matching function by making the assumption that the intensity of search is a choice variable. We de..ne intensity of search as the number of "units" of search supplied by a given individual. Units are de..ned as follows. If individual i supplies $\mathrm{S}_{i}$ units of search and individual $\mathrm{j}$ supplies $\mathrm{s}_{\mathrm{j}}$ units, then in a small time interval individual $i$ is $s_{i}=s_{j}$ times more likely than individual $j$ is to ...nd a match. Search units are supplied at a cost, which is normally increasing, and they are chosen optimally to maximize the net returns from search (see Pissarides, 2000, chapter 5). Therefore, dixerent individuals will choose dixerent number of search units, depending on their search costs, the cost of unemployment and the expected returns from employment.

To derive the matching function implied by this extension, let $\mathrm{s}$ be the average number of search units supplied by an unemployed person. ${ }^{5}$ Then, the total number of search units supplied is $\mathrm{SU}$; and so the aggregate matching function is

$$
\mathrm{M}=\mathrm{m}(\mathrm{sU} ; \mathrm{V}) ;
$$

a more general form of (3.5). Of course, varying intensity could also be introduced for job vacancies, in symmetric fashion. The hazard rate for an individual who supplies $\mathrm{s}_{i}$ units of search is $\mathrm{s}_{i} \mathrm{~m}(\mathrm{sU} ; \mathrm{V})=\mathrm{sU}$ : The fact that this function depends on individual characteristics through the optimal choice of intensity of search justi..es the econometric estimates of hazard functions that make use of individual survey data. On average, the representative individual will choose intensity s; so the average transition rate for unemployed workers, which can be used in macro modeling, is $\mathrm{m}(\mathrm{sU} ; \mathrm{V})=\mathrm{U}$ :

A nother channel through which heterogeneity can infuence the matching function and market outcomes arises when there is a distribution of wage oxers. The distribution may be due to either identical .rms oxering dixerent wages, as in the model of Burdett and Mortensen (1998), or to match heterogeneity, as in the model of J ovanovic (1979). The individual chooses a reservation wage and

\footnotetext{
${ }^{5} \mathrm{~T}$ his $\mathrm{s}$ bears a close resemblence to the $\mathrm{s}$ of the preceding section, which explains the use of a common symbol.
} 
rejects all wage oxers below the reservation. In equilibrium models the reservation wage for each job that the worker encounters is such that neither the ..rm nor the worker will want to form a match if the wage is below reservation (see P issarides, 2000, chapter 6). Of course, if individual characteristics dixer, workers may choose dixerent reservation wages.

Let $\mathrm{m}(\mathrm{U} ; \mathrm{V})$ be the technology that brings vacant jobs and unemployed workers together. When a pair meets it is faced with a wage oxer w; which is assumed to be a drawing from a probability distribution $\mathrm{G}(\mathrm{w})$ : If the probability distribution is known to job seekers the optimal policy of individual $i$ is characterized by a reservation wage $R_{i}$; such that the job is accepted if $w, R_{i}$; rejected otherwise. The hazard rate for this individual is $\left[1 ; G\left(R_{i}\right)\right] m(U ; V)=U$ : A ggregation over all individuals gives the average transition rate and from there, multiplication by the unemployment rate gives the aggregate matching function. Clearly, given that in general the probability $G\left(R_{i}\right)$ is non-linear, the aggregate function takes a rather complicated form, but to a ..rst approximation we can de.ne $\mathrm{R}$ as the average reservation wage and write the aggregate matching function as

$$
M=[1 ; G(R)] m(U ; V):
$$

As with the function derived for variable search intensity, (3.6), this function justi..es the introduction of aggregate variables that in $\ddagger$ uence individual decisions during search into estimated matching functions. The variables can be demographic variables that inłuence the intensity of search - for example, if youths search with lower intensity than adults the youth share in the population should be a shift variable. Or they can be variables that in $\neq$ uence the cost of search and moving, such as unemployment insurance variables and housing transaction costs. The list of variables that can in $\neq$ uence search intensity and reservation wages has been a fertile ground for searching for statistically signi..cant shift variables in empirical matching functions, an issue discussed in the empirical sections that follow.

\subsection{Ranking}

Blanchard and Diamond (1994) consider the alternative assumption that ..rms receive many applications at a time and have preferences over job applicants. They rank applicants and oxer the job to the person ..rst in the rank. Their motivation for studying this process is a feature of European labor markets, that with the rise in unemployment durations, the long-term unemployed became "disenfranchised" and less good employees than those with more recent work experience. 
The matching function used by Blanchard and Diamond (1994) is similar to the urn-ball function (3.2) but the implications of the ranking principle can be illustrated more generally. Suppose the unemployed are divided into two groups, the short-term unemployed and the long-term unemployed. Let the number of short-term unemployed be $U_{S}$ and the number of long-term unemployed be $U_{L}$ : Then, if a short-term and a long-term unemployed compete for the same job, the short-term unemployed always gets it. Therefore, the long-term unemployed do not cause congestion for the short-term unemployed during search and the longterm unemployed get only jobs for which there are no short-term applicants. The implication of the ..rst claim is that the matching function for the short term unemployed is $\mathrm{m}^{\mathrm{S}}\left(\mathrm{U}_{\mathrm{S}} ; \mathrm{V}\right)$; where $\mathrm{V}$ are all the vacancies, and the matching function satis..es all the properties of (2.1). If the long-term unemployed knew which vacancies are now being taken by the short-term unemployed, their matching function would be $\mathrm{m}^{\mathrm{L}}\left(\mathrm{U}_{\mathrm{L}} ; \mathrm{V} ; \mathrm{M}^{\mathrm{S}}\right)$ : But more generally, if there is a coordination failure between short-term and long-term unemployed, we write as usual $\mathrm{m}\left(\mathrm{U}^{\mathrm{S}}+\mathrm{U}^{\mathrm{L}} ; \mathrm{V}\right)$ for total matches and then attribute the dixerence between $\mathrm{M}$ and $\mathrm{M}^{\mathrm{S}}$ to matches involving long-term unemployed. That is, the aggregate matching function is

$$
M=m\left(U^{S}+U^{L} ; V\right)
$$

but the hazard rate for the short-term unemployed is $m^{S}\left(U^{S} ; V\right)=U^{S}$ and for the long-term unemployed $\mathrm{m}\left(\mathrm{U}^{\mathrm{S}}+\mathrm{U}^{\mathrm{L}} ; \mathrm{V}\right)=^{\mathrm{L}} ; \mathrm{m}^{\mathrm{S}}\left(\mathrm{U}^{\mathrm{S}} ; \mathrm{V}\right)=^{\mathrm{L}}:^{6}$ Simple calculations show that if the matching functions are identical the hazard rate of the short-term unemployed is always higher than the hazard rate of the long-term unemployed.

Blanchard and Diamond (1989) estimate a speci..cation similar to (3.8) and impose that the short- and long-term unemployed are perfect substitutes up to a scale parameter. If the estimated value of this parameter is below one it is evidence in favor of the ranking hypothesis. Their point estimate of the scale parameter, however, slightly exceeds one, but is not signi..cantly dixerent from zero.

\subsection{Stock-łow matching}

The matching functions discussed so far were derived under the assumption that job seekers take a vacant job at random and apply for it. This assumption is

\footnotetext{
${ }^{6} \mathrm{~N}$ ote that the expected duration of unemployement of the long-term unemployed is the inverse of their hazard rate but for the short-term unemployed account has to be taken of the fact that if they survive to long-term unemployment, their hazard rate will fall.
} 
convenient and realistic in many situations, given that there is an element of luck in hearing about job oxers. But there is also a systematic element in search. This sub-section and the next discuss the derivation of an aggregate matching function from assumptions that go to the other extreme of no randomness in job applications.

Coles (1994) and Coles and Smith (1998) consider the implications of the assumption that job seekers have complete information about the available job vacancies and apply simultaneously to all the ones that they think are likely to be acceptable. Let this number be the entire universe of jobs on oxer. But because of heterogeneity, not all job matches turn out to be acceptable. Let a constant $\circledR$ be the probability that a job match is unacceptable to the pair. A matching round then begins in a "marketplace". J ob-worker pairs that made contact and are unacceptable are rejected. T he remaining acceptable ones are sorted out so that no ..rm and worker who could form an acceptable match remain unmatched. Thus, unlike the urn-ball process of the preceding example, there is no coordination failure in this case. Those workers who remain unmatched do so because there are no vacancies that are suitable for them among the existing pool.

It follows that no job vacancy or unemployed worker who has been through one round of matching will attempt to match again with a pre-existing job seeker or vacancy. Of course, the assumption that the length of time when job seekers and vacant jobs get to know each other is one matching period is a simplifying one. Coles and Smith's assumption captures a realistic feature of search markets, that a job seeker scans a lot of advertisements before deciding where to apply and once an advertisement has been scanned and rejected, return to it is less likely than application to a new advertisement.

Under Coles and Smith's assumption there is a sharp distinction between the stocks of unemployed workers and vacant jobs and the new in $\ddagger$ ows. The stock of unemployed workers at the beginning of the period will not match with the stock of vacant jobs also at the beginning of the period, because they were both participants in the matching round in the previous period. The resulting matching process is therefore one where the unmatched stock of traders on one side of the market is trying to match with the $¥$ ow of traders on the other side. This is often referred to as "stock- $¥ 0$ " matching. ${ }^{7}$

Let the stocks at the beginning of the period be $U_{0}$ and $V_{0}$ : If the fow of new unemployed workers and new job vacancies into the respective pools during the period are $U_{1}$ and $V_{1}$, the $U_{0}$ initial workers match with the new infow $V_{1}$ only,

\footnotetext{
${ }^{7}$ Coles (1999) discusses the turnover externalities implied by stock- $¥$ ow matching.
} 
whereas the infow $U_{1}$ matches with both $V_{0}$ and $V_{1}$ : Coles and Smith consider a period of in..nitesimal length and so ignore the probability of a newly unemployed worker matching with a newly created vacant job. In this case, the probability that a new vacancy is matched on entry is $1 ; \quad \mathbb{B} \mathbb{J}_{0}$; so the matches due to new vacancy creation are $V_{1}\left(1 ; \quad \mathbb{B}^{V_{0}}\right)$ : Recall that $\circledast$ is the probability that a random pairing is unacceptable. The probability that a new worker is matched on entry is $1_{i} \quad{ }^{\circledR} / 0$ and so the new matches due to the new entry of workers is $U_{1}\left(1_{i}{ }^{\circledR}{ }^{10}\right)$ : Since there are no matches between old unemployed and old vacancies, the sum of the two matches gives the entire matching rate in the economy. That is, the matching function is

$$
M=V_{1}\left(1 ; \quad \AA^{U^{0}}\right)+U_{1}\left(1 ; \quad \mathbb{R}^{V_{0}}\right) ;
$$

with $1>{ }^{\circledR}>0$.

The hazard rate for workers who are unemployed at the beginning of the period is $V_{1}\left(1_{i} \mathbb{B}^{V_{0}}\right)=J_{0}$ and for the new in $\neq$ ow $1_{i} \quad \mathbb{B}^{\mathbb{N}} 0$ : The latter is likely to be smaller because for the short period under analysis, the stock of jobs and workers is likely to be much bigger than the new fow, i.e., $V_{1} i \quad V_{0}$ and $V_{1} i \quad U_{0}$ :

The matching function in (3.9) exhibits increasing returns to scale in the stocks and the $\ddagger$ ows, although it is not homogeneous. The reason is that job seekers apply to all the available job vacancies simultaneously. If we double the number of job vacancies and unemployed workers, the applications of each and every job seeker double. This contrasts with the matching function in (3.2), where each job seeker applies only to one job and so doubling the number of jobs doubles the number of applications. Applying to more than one vacancy at a time is a realistic feature of the application process but it depends on a constant rejection probability ${ }^{\circledR}$. When the rejection probability is endogenized, we would expect it to increase when the matching probability increases. Intuitively, the model captures the fact that in a large market job seekers have more options but not the fact that they would be more choosy as a result.

The model implies that the matching probability for the unemployment infow does not suxer from congestion, whereas the preexisting unemployed suxer congestion from each other. This result derives from the assumption that newcomers łow into the market individually, given the continuous time structure of the matching process that takes place across time periods of in..nitesimal length. If instead we consider time periods of discrete length, a newly unemployed can match with a new vacancy, and at the same time all the newly unemployed can cause congestion to one another when trying to match with existing vacancies. 
The extra congestion externalities generated in this case are shown by Gregg and Petrongolo (1997) to rule out increasing returns to scale.

Stock-łow matching has received some empirical support. Coles and Smith (1998) argue that, due to stock- $¥$ ow matching, exit rates are higher when traders ..rst enter the labor market, and drop sharply thereafter. This suggests that traders who are unlucky at their ..rst round of search need to wait and queue for new entrants in order to ..nd a suitable match. There are, however, many other reasons for the fall in unemployment exit rates, which include ranking, discouragement and loss of skills during unemployment. But more detailed evidence on matching combinations among labor market participants shows that stock-łow matching plays a signi..cant role in raising the matching probabilities of recently unemployed workers.

Coles and Smith estimate a log-linear matching function dividing the out $\neq$ ow from unemployment into duration classes. They ...nd that both the stock and the in $¥$ ow of vacancies increase the unemployment out $\ddagger$ ow at short durations of search but at longer durations only the inłow of new vacancies increases signi..cantly the job ..nding rates of the unemployed. Qualitatively similar results are also found by G regg and Petrongolo (1997), who estimate quasi-structural outłow equations for unemployment and vacancies derived from a stock-łow matching model in discrete time.

\subsection{Aggregation over distinct markets}

We ..nally discuss a derivation of the aggregate matching function that relies on the existence of disequilibrium in micro markets and limited mobility of labor. The assumption is that the economy is divided into micro markets that do not suxer from frictions but suxer from a disequilibrium in the sense that the demand for labor in each market is not equal to the supply. There is no mobility of labor or capital between markets. This assumption can be interpreted as the source of the friction that gives rise to the aggregate matching function. It implies that markets with unemployment can co-exist with markets with job vacancies although no market has both. A ggregation over all markets gives an aggregate function that contains both vacancies and unemployment. With perfect mobility workers would move until the short side of the aggregate economy cleared and no aggregate matching function would exist.

A model of this form was ..rst used by Hansen (1970) to derive the Beveridge curve (see also Holt, 1970b). Other studies that follow this approach are D rèze and 
Bean (1990), Bentolila and Dolado (1991) and Franz (1991). Borrowing results discussed by Drèze and Bean (1990, p. 14), who credit Lambert (1988) for the derivations, suppose that the ratio of vacancies to unemployment in each micro market is lognormally distributed. Then, if the short side of each market clears and $\mathrm{U}$ and $\mathrm{V}$ are the aggregate quantities, there is a CES-type relationship that could be interpreted as an aggregate matching function

$$
M=U^{i^{1 / 2}}+V^{i^{1 / 2}} i^{1=1 / 2} ;
$$

where $1 / 2>0$ is related to the variance of the ratio of unemployment to vacancies across micro markets.

The derivation of this matching function needs the assumptions of exogenous distributions of unemployment and vacancies across space. Lagos (1997) derives instead optimal rules for the allocation of agents across space, under the assumption that there is uncertainty about the number of agents at each location. He shows that the resulting matching equilibrium is one where the short side of the market clears - but now the number of agents on one side is optimally selected (see also Lagos and Violante, 1998).

As far as we are aware, there are no tests of this microfoundation for the aggregate matching function. A key problem here is to de..ne the unit of the micro market. If a micro market is in..nitesimally small, and consists of at most one job each, the assumption is trivially correct. If it is large and equal to the economy as a whole, the assumption is incorrect, since at the aggregate level vacancies and unemployment co-exist. A travel-to-work area would appear to be the most appropriate disaggregation level but no tests have been conducted at this level. A nother dic culty with the CES form is that it relies on distributional assumptions about unemployment and vacancies and a test of the CES restrictions (e.g. versus Cobb-Douglas) would need to test the validity of the distributional assumptions as well. ${ }^{8}$

\section{Empirical M ethods and Findings}

In the matching framework the equilibrium levels of unemployment and job vacancies that persist in steady state are the result of the intensity of the job reallocation

\footnotetext{
${ }^{8} \mathrm{G}$ raph theory can also potentially be used to derive results about the interaction of agents in markets with frictions, although there are as yet no clear-cut implications for the aggregate matching function. See loannides (1997).
} 
process and of the matching exectiveness of the labor market. One way of making inferences about the empirical properties of the matching function is to estimate such a long-run vacancy-unemployment relationship, the UV or Beveridge curve. The advantage from taking this indirect route is that estimation of the B everidge curve requires only data on stock variables, not $\ddagger$ ows, which are more readily available. The early literature on matching followed mainly this approach. But partly because of the dic culty of making accurate inferences about the matching function from estimated Beveridge curves (outlined below) and partly because the connection between the matching function and the Beveridge curve became better understood, most of the empirical literature since the late 1980s and early 1990s estimated directly the matching function. As more data became available estimated matching functions appeared in the literature making use of aggregate time-series for the whole economy or for some sector (most frequently manufacturing), panel data for regions or districts, and data on individual re-employment hazards. We review the main results of each approach with focus on the results not previously discussed.

\subsection{B everidge curves}

A steady-state Beveridge (or UV) relationship between the unemployment rate and the vacancy rate can be derived from the simple matching function (2.1). Let $\mathrm{U}$ and $\mathrm{V}$ be the number of unemployed workers and job vacancies respectively, and $\mathrm{N}$ and $\mathrm{L}$ the level of employment and the labor force (so $\mathrm{L}=\mathrm{N}+\mathrm{U}$ ): De. ne the unemployment rate $\mathrm{U}=\mathrm{U}=\mathrm{L}$ and let the vacancy rate be $\mathrm{V}=\mathrm{V} \neq \mathrm{V}$ (an inconsequential change from the alternative $v=V \notin$ ). A ssume also that the job separation rate is,; so total separations are $\mathrm{S}=, \mathrm{N}$ : Then, imposing constant returns to scale on $\mathrm{m}(:)$ and noting that in steady state the number of matches $M$ equals the number of job separations $S$, we get the Beveridge curve, ${ }^{9}$

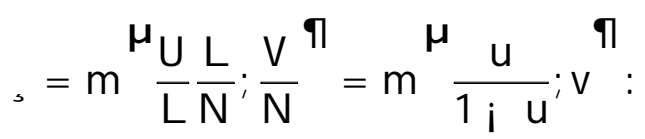

Given the separation rate, ; our assumptions on $\mathrm{m}(:)$ imply a negative steadystate relationship between the unemployment rate and the vacancy rate.

A $n$ aggregate Beveridge curve of the form of equation (4.1) was estimated by a number of authors for the aggregate stocks of vacancies and unemployment

\footnotetext{
${ }^{9} \mathrm{~N}$ ote that constant returns in $\mathrm{U}$ and $\mathrm{V}$ are not needed here. Suppose for example that the matching function has constant returns in $\mathrm{U} ; \mathrm{V}$ and $\mathrm{N}$; as in (3.3) but increasing returns in $\mathrm{U}$ and $\mathrm{V}$ : Then dividing through by $\mathrm{N}$ gives an expression with properties similar to (4.1).
} 
(see for example J ackman and Roper 1987, Budd et al. 1988, J ackman et al. 1989 and Wall and Zoega 1997 for Britain, A braham 1987 for the US, Franz 1991 for Germany, Edin and Holmlund 1991 for Sweden, B runello 1991 for J apan and J ackman et al. 1990 for a multi-country study). The form preferred is usually log-linear, which implies a Cobb-Douglas matching function if the foundation for the Beveridge curve is the aggregate matching function. All studies establish the existence of a negative long-run relationship between the vacancy rate and the unemployment rate, as implied by (4.1). But virtually all studies also identify some shift variables, not present yet in (4.1).

Of course, (4.1) is consistent with many dixerent micro frameworks, some perhaps unrelated to the matching framework. But if we posit that there is an aggregate matching function underlying (4.1), some lessons immediately emerge from the Beveridge curve studies about the properties of the matching function.

First, there is support for the restrictions on the simple two-variable matching function, including some tentative evidence for constant returns. The negative convex-to-the-origin shape predicted by the model ..ts the data well and in the cross-country regressions country size does not appear to be an infuence on the position of the Beveridge curve, something that would be implied by some models of increasing or decreasing returns to scale. But no study conducts a careful test of increasing returns to scale by testing, for example, whether the matching rate improves when the total number of participants increases for given ratio of vacancies to unemployment, or whether there are increasing returns to $\mathrm{U}$ and $\mathrm{V}$ but constant returns to $\mathrm{U} ; \mathrm{V}$ and $\mathrm{L}$; as implied for example by (3.3).

Second, there have been shifts in the relationship, especially in E uropean countries. These shifts coincide with the secular rise in European unemployment, which started in the mid 1970s. The unemployment rate has increased despite the fact that the separation rate and the vacancy rate, , and $v$ in (4.1), have not shown any trend. The implication for the matching function is that there are variables besides $u$ and $v$ that have played an important role in matching in the last two decades and these variables contributed to a deterioration of the matching rate.

$R$ easons that have been suggested in the literature include mismatch ( $\mathrm{J}$ ackman et al., 1989) - which as we have seen may explain some but not much of the shift - the growth in long-term unemployment, which reduces both the search intensity of the unemployed and their employability through loss of skill (Budd et al. 1988), the generosity of the unemployment insurance system (J ackman et al. 1989) and active labor market policy (J ackman et al. 1990). J ackman and Roper (1987) have shown that in Britain the shifts in the regional Beveridge curves were of 
the same order of magnitude as the aggregate curve, casting more doubt on the power of regional mismatch to explain the shift in the aggregate curve. On a more positive note, J ackman et al. (1990) show that the dixerent position of the estimated Beveridge curves in Europe is positively correlated with their spending on active labor market policies. Countries with more spending on policies that aid matching have Beveridge curves closer to the origin.

But on average no single or combination of variables can account for the deterioration of the matching rate since the mid 1970s, and the literature often attributes it to unmeasured elements of the unemployment insurance system and mismatch. It is interesting that measured components of the unemployment insurance system do not play a role in the deterioration of the matching rate. Unmeasured elements mentioned in the literature are usually statements about the leniency of the system and its coverage. In the estimation such measures are usually picked up by time trends, which could of course account for many other unobserved or unidenti..ed inłuences on matching.

Estimation of log-linear UV curves, along the lines followed by most of the studies mentioned, suxers from some problems, connected with the assumption of fow equilibrium, the endogeneity of the separation rate and the fact that inferences about the micro process underlying matching cannot be easily made from such an aggregate framework. More recent studies estimate matching functions by making use of $\ddagger$ ow data, which are more disaggregated and do not have to rely on either a constant (or exogenous) job separation rate or $\ddagger$ ow equilibrium.

\subsection{Aggregate studies}

Table 1 gives a summary of the speci..cations and the results of studies that have estimated aggregate matching functions. Pissarides (1986) estimates an aggregate matching function for B ritain over the period 1967-1983. The speci..cation adopted uses quarterly data with the average monthly out $\neq$ ow rate from male unemployment during the quarter as the dependent variable. The unemployment series used is for registered male unemployment and the series for vacancies is noti..ed vacancies adjusted upwards for incomplete coverage. ${ }^{10}$ R esults with both

\footnotetext{
${ }^{10} \mathrm{R}$ eported vacancy data are generally unreliable. In several countries (including the United $\mathrm{K}$ ingdom, France, Germany and Israel), data on job vacancies are collected on a regular basis. The data, however, are for vacancies noti..ed to state employment agencies and they suxer from under-reporting, with the exception of some rare instances where reporting is mandatory (see, e.g. Yashiv, 2000). In addition, the proportion of vacancies noti..ed varies with general economic conditions, both aggregate and sectoral (see J ackman et al., 1989). J ackman et al. suggest an
} 
linear and log-linear speci..cations are reported. The estimated log-linear speci... cation is

$$
\begin{aligned}
\ln ^{\mu} \frac{M}{U}_{t}{ }^{q}= & { }_{0}+{ }_{1} \ln { }^{\mu} \bar{v}^{q}{ }_{t}+{ }_{2} t+{ }_{3} t^{2} \\
& + \text { lags + structural variables. }
\end{aligned}
$$

B oth the linear and log-linear speci..cation strongly support constant returns to scale in $\mathrm{U}$ and $\mathrm{V}$ (see Table 3 ). The estimated elasticity of matches with respect to vacancies is 0.3 with an implied elasticity of matching with respect to unemployment 0.7. No other variables were found to be signi..cant except for the time trends, which indicate a large fall in the rate of job matches at given unemployment and vacancy rate during the sample period.

Later estimation of a similar regression by Layard et al. (1991, chapter 5) for 1968-1988 found similar elasticity estimates but also found that the rise in longterm unemployment reduces the matching rate at given unemployment rate. But the time trend remains signi..cant in their regression. Also, the authors do not deal with the endogeneity of long-term unemployment but measure its impact by computing an index for duration exects. This index is a weighted average of duration with ..xed weights that are proportional to the outłow rates from each category in a base year. The fact that out $\neq$ ow rates fall with duration and duration increases during the sample gives an upward trend to the index, which is positively correlated with the trend in unemployment.

Long-term unemployment has been a frequent candidate for shifts in the aggregate matching function (see Budd et al., 1985). Although this is related to Blanchard and Diamond's (1994) idea of ranking, it is more general, in the sense that the claim being made is that the average matching rate should be higher the lower the incidence of long-term unemployment. ${ }^{11}$ Denoting again the stock of short-term unemployed by $U_{S}$ and the stock of long-term unemployed by $U_{L}$; this implies that the aggregate matching function takes the form

adjustment method to correct for the under-reporting, which makes use of information contained in the fraction of job matches realized through state employment agencies. In the United States these is no comparable vacancy series. The proxy most frequently used is the help-wanted index, which is based on the counts of job advertisements in major metropolitan newspapers. (see A braham 1987).

${ }^{11} \mathrm{~N}$ ote that the way that we formalized the ranking idea in equation (3.8) does not justify the claim made in the text about average matching rates. Ranking axects only the distribution of matches across the unemployed. But the frequently-made assumption that the long-term unemployed reduce their search intensity or lose their skills would justify it. 


$$
M=m U^{\tilde{A}}+U^{L} ; V ; \frac{U^{L}}{U^{S}+U^{L}}
$$

where the last variable included should have a negative impact on the matching rate. This prediction is con..rmed by Burgess (1993) for Britain, Mumford and Smith (1997) for Australia, and Bell (1997) for Britain, France, and Spain. The speci..cation adopted by Layard et al. (1991), is similar to the one in (4.3) but with the alternative measure of long-term unemployment described above.

Blanchard and Diamond (1989, 1990b) estimate a matching function for the United States over the period 1968-1981. The estimated equation is a log-linear speci..cation in levels

$$
\ln \mathrm{M}_{\mathrm{t}}=\mathbb{B}_{0}+\mathbb{B}_{1} \ln \mathrm{U}_{\mathrm{t}}+\mathbb{B}_{2} \ln \mathrm{V}_{\mathrm{t}}+\mathbb{R}_{3} \mathrm{t} ;
$$

where the log of monthly national hirings is used as the dependent variable, unemployment is interpreted as a proxy for all job seekers (including employed and out-of-thelabor force) and the vacancy series was constructed from the helpwanted index. The estimated elasticities of matches with respect to vacancies and unemployment are positive and signi...cant, and the time trend generally comes in with a negative and signi..cant coeф cient (but smaller than in Britain or other large European countries), implying a deterioration in the matching exectiveness of the labor market since the late 1960s. They ..nd clear evidence of the existence of an aggregate matching function with constant or mildly increasing returns to scale, unit elasticity of substitution, and weights of 0.4 and 0.6 on unemployment and vacancies respectively. But the weight 0.4 is found when the unemployment rate is used as a proxy for all job seekers, which may not be appropriate when the number of employed job seekers is pro-cyclical; when the left-hand side variable is restricted to include only job matches from unemployment, the weight on unemployment rises to 0.6 .

The higher unemployment elasticity of matching found in the British studies can be the result of the dixerent dependent variable used. Pissarides (1986) and Layard et al. (1991) use the total out ow from unemployment whereas Blanchard and Diamond $(1989,1990 \mathrm{~b})$ construct a $\ddagger$ ow variable that approximates the total number of hires (including job-to-job moves and łows from inactivity directly into employment, a point that is not relevant here but addressed in the next section). B urda and W yplosz (1994), who estimate log-linear matching functions for France, Germany and the United K ingdom by regressing total exits from unemployment 
on vacancy and unemployment stocks, also found high elasticities of matches with respect to unemployment, in the range 0:5 i 0:7.

To see more formally the point that we are making, let $X$ denote total exits from unemployment and $M$ denote total hires, again from unemployment. Let also $D$ denote exits from unemployment to out of the labor force, a combination of "discouraged" worker exects, early retirement and going back to school. Let $M$ be a log-linear constant returns to scale function of the type estimated by Blanchard and Diamond and $D$ depend on vacancies with elasticity $i$ and on unemployment with elasticity ${ }^{-}$: If the tightness of the market $V=U$ is a good measure of the cycle (as it is likely to be under constant returns, see Pissarides, 2000), and movements from unemployment to inactivity depend only on the cycle, we expect $B==^{-}$: B ut if the experience of unemployment has additional infuences on retirement and dropping out, we should expect on a priori grounds ${ }^{-}$, $_{\text {. The }}$ function estimated by the European studies is (with constants omitted)

$$
\begin{aligned}
X & =M+D \\
& =U^{\prime} V^{1_{i}}+U^{-} V^{i{ }^{\circledR}:}
\end{aligned}
$$

Studies that use a measure of $\mathrm{M}$ in their regressions estimate ' directly. Blanchard and Diamond's estimate for this number is 0:6 and similar estimates (in the range 0:55 i 0:70) are found by van Ours (1995), Boeri and Burda (1996) and Burda and Pro..t (1996) for other countries.

Studies that use $X$ as dependent variable in a log-linear regression approximately estimate

$$
\begin{aligned}
\frac{@ X}{\text { CD }} \frac{U}{X} & ={ }^{\prime} \frac{M}{X}+\frac{-D}{X} \\
& ={ }^{\prime}+\left(^{-} i^{\prime}\right) \frac{D}{X}
\end{aligned}
$$

and

$$
\begin{aligned}
\frac{@ X}{@ V} \frac{V}{X} & =\left(1 i^{\prime}\right) \frac{M}{X} i \stackrel{\circledR}{X} \\
& =1 i^{\prime} i\left(1 i^{\prime}+\circledast\right) \frac{D}{X}:
\end{aligned}
$$

The elasticity estimate obtained by studies that use the total exit as dependent variable should be lower for vacancies and, if ${ }^{-}{ }^{>}{ }^{\prime}$; higher for unemployment. 
Moreover, given that both sets of studies ..nd constant returns to scale, the parameters must be such that

$$
\text { - }=1+\mathbb{B}
$$

This necessarily implies that ${ }^{-}>\mathbb{R}$, that is, the experience of unemployment has an independent infuence on dropping out of the labor force, in addition to its cyclical inłuence.

Blanchard's and Diamond's estimate of 0:6 for '; the Pissarides-Layard et al. estimate of 0:7 for the unemployment elasticity of total exits, and a plausible mean value for the ratio $D=X$ (the fraction of unemployment exits that leave the labor force) of $0: 4^{12}$ give $^{-}=0: 85$ and a negative value for $\mathbb{R}$ T hese numbers, however, are derived from the dixerence between a point estimate of $0: 6$ and one of $0: 7$ and they are sensitive to small changes in these estimates. Given the estimates, a useful approximation that is well within the con..dence interval of the elasticity estimates is one where ${ }^{\circledR}=0$; i.e. one with implied total exit from unemployment of

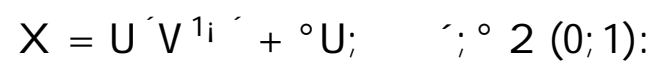

Blanchard and Diamond (1989, 1990b) also estimate equation (4.4) for the US manufacturing sector alone. The results that they obtain in this case are broadly consistent with the aggregate ones, with the important quali..cation that the manufacturing matching function displays increasing rather than constant returns to scale. The estimated sum of the elasticity of matches with respect to vacancy and unemployment is now 1.4 (see Table 3). Estimates for US manufacturing are also reported by Warren (1996) who estimates a more ‡exible translog function for all manufacturing for 1969-1973, when a vacancy series for this sector was available. The translog speci...cation gives a more accurate estimate of the returns to scale of a technology than the Cobb-Douglas form (see Guilkey et al. 1983). The dependent variable in Warren's study is total hires in manufacturing and the unemployment variable consists of all those currently unemployed who previously held jobs in the manufacturing sector. The correspondence of the $\neq$ ow variable that is used as dependent variable with the stock on the right hand side is poor but almost inevitable when hires in only one sector are used. He..nds statistically signi..cant increasing returns to scale with sum of coec cients on vacancies and unemployment of 1.33. Similar results are found by Yashiv (2000), on both a log-linear and a translog matching function for the whole Israeli economy over the

\footnotetext{
${ }^{12}$ T his is obtained from the data on worker łows reported by Burda and W yplosz, 1994.
} 
period 1975-1989. The estimated returns to scale in his matching function lie in the range 1.20-1.36.

The other studies summarized in Table 1 generally con..rm the results of the earlier studies discussed in this section for dixerent countries and time periods.

\subsection{Sectoral studies}

The dic culty with making inferences about labor market matching from aggregate time series beyond the initial results of the studies discussed in the preceding section led many authors to switch to more disaggregate speci..cations, either in panel or single cross-sections. Table 2 summarizes results for a number of sectoral studies.

A nderson and Burgess (2000) estimate a state-industry panel for the United States over the period 1978-1984, using a similar speci..cation to Blanchard and Diamond's (1989) aggregate study. They also include variables for sex and age composition of the labor force and the degree of unionization, and distinguish new hires by origin, namely whether they come from employment or non-employment. Although the sum of estimated elasticities is well above one when hires from employment are used as the dependent variable, in neither case can the constant returns hypothesis be rejected at the conventional signi..cance levels.

In an attempt to apply the matching function analysis to local labor markets, Coles and Smith (1996) and Bennet and Pinto (1994) both provide cross-section estimates of the matching function for local labor markets in Britain. Local labor markets are represented in Coles and Smith (1996) by travel-to-work areas. They use data for 257 areas in 1987 and estimate a regression for total hirings. As in the US studies they ...nd an elasticity of 0.7 on vacancies and 0.3 on unemployment. Their study also shows the importance of the geographic density of unemployment and vacancies in the hiring process, with more concentrated labor markets having higher matching rates. The analysis of Bennet and Pinto (1994) uses instead data from Training and Enterprise Councils, estimating a time series for each (Britain is divided into about 100 such areas). They ..nd that the parameters of the matching technology do not vary substantially across districts, the elasticities being within a narrow range of 0.5 for both unemployment and vacancies, and therefore con..rm that there are no serious problems of aggregation.

The Coles and Smith and the B ennet and Pinto studies treat local labor markets as isolated marketplaces. Interactions among neighboring districts are modeled by Burda and Pro..t (1996), Burgess and Pro..t (1998), and Petrongolo and 
Wasmer (1999), who ..nd evidence of matching spillovers across space but with smaller coec cients for neighboring districts. This ..nding highlights the importance of moving costs in matching and is consistent with Coles' and Smith's ..nding that population density matters in local matching rates. We take up the issue of spatial aggregation below.

\subsection{M icro studies}

The estimation of reemployment probabilities for unemployed individuals has the potential of distinguishing between the determinants of the probability of receiving a job oxer and that of accepting it. The former depends on the set of characteristics that infuence a worker's productivity (such as age, education and experience) and on local labor demand conditions, which is the exect captured by aggregate matching functions. The second probability depends on a worker's reservation wage, and therefore on the expected distribution of wages, the cost of search, unemployment income and the probability of receiving a job oxer.

Structural studies (see Ki iefer and Neumann 1979a,b, 1981; Flinn and Heckman 1982, Narendranathan and Nickell 1985; Wolpin 1987; and Eckstein and Wolpin 1995) identify separately an accepted wage equation and a wage oxer equation, and so they can distinguish between the determinants of each of these probabilities. Reduced-form or hazard function studies estimate instead the factors axecting the product of the two probabilities, namely the transition of workers from unemployment to employment, and are therefore more directly comparable with matching function studies.

Despite this connection, however, micro studies have not been used in the empirical search literature to make inferences about the properties of the aggregate matching function, with very few exceptions. Their contribution can be twofold. Micro studies control for a number of individual characteristics which can be aggregated to give shift variables in the aggregate matching function besides $U$ and V: They can also be used to test for the exect of local labor market conditions on re-employment probabilities and from there aggregate to make inferences about the in $¥$ uence of local conditions on aggregate matching.

The early study by Lancaster (1979) uses a sample of British unskilled male workers to show that exit rates from unemployment are negatively axected by age, the duration of search, and the local unemployment rate. The age exect in the job-...nding hazard implies that the age composition of the labor force should play a role in aggregate matching function estimates, with a younger pool of job-seekers 
delivering higher exit rates from unemployment (see for example Coles and Smith 1996 and Anderson and Burgess 1995). Negative duration dependence in job search implies that the incidence of long-term unemployment should reduce the unemployment outłow in aggregate speci..cations, which is con..rmed by, among others, Layard et al. (1991) and Burgess (1993). Finally, the negative exect of unemployment captures the congestion exect of a larger pool of job-seekers on individual job-..nding rates. This should translate into an aggregate elasticity of matches with respect to unemployment less than 1 , which is the case in all aggregate studies.

Following Lancaster's application of duration models to re-employment probabilities, a large number of papers have studied the determinants of exit rates from unemployment, looking at a variety of speci..cations and control variables. ${ }^{13}$ Perhaps surprisingly, a result that frequently appears in the micro studies but not in aggregate studies is the infuence of the unemployment insurance system (see Nickell, 1979 and Narendranathan et al. 1985). Although there are dissenting voices (e.g. Atkinson et al. 1984), on balance micro studies ..nd a (small) infuence of unemployment insurance on re-employment probabilities. A ggregate studies have failed to ..nd a robust exect, perhaps because of the complexity of the system and the diф culty of measuring accurately its dimensions in a time series. For example, it has been claimed that the duration of unemployment bene.ts is the most important dimension of the system that infuences matching. But because there is very little time-series variation in the duration of entitlements, only cross-country data can be used to test for this exect. Yet, in cross-country regressions variations in durations are also limited, with some countries having unlimited durations and some restricting it to six or twelve months (see OECD, 1994, Pissarides, 1999). Another dimension of the unemployment insurance system that has been emphasized in descriptive work is the leniency of the system. In a time series it is dic cult to get a good measure of leniency.

In conditioning on the state of the local labor market, only a few micro studies (Nickell, 1979, Atkinson et al. 1984, Lindeboom et al. 1994 and Petrongolo, 2000) take into account the demand side of the labor market and employers' search, by controlling for the local vacancy-to-unemployment ratio. A higher labor market tightness, represented by the $\mathrm{V}=U$ ratio, signi..cantly increases the

\footnotetext{
${ }^{13}$ See Devine and Kiefer (1991) for a survey of hazard studies. Despite a rich literature on the study of unemployment exit rates, little work has been done so far on vacancy durations. Notable exceptions are van Ours and Ridder $(1992,1993)$ and, more recently, Burdett and Cunningham (1998).
} 
job-..nding hazard in these studies, con..rming the results of aggregate studies. Petrongolo (2000) also tests of the infuence of the size of the local market on reemployment probabilities. Re-employment probabilities are conditioned on the number of unemployed workers and vacancies within the travel-to-work area of each worker. The coed cients on $\ln U_{t}$ and $\ln V_{t}$ are estimated separately and found to be not signi..cantly dixerent from each other across a number of dixerent speci..cations, which con..rms constant returns to scale in matching. ${ }^{14}$

\section{Search on the $\mathrm{J}$ ob and out of the Labor Force}

A large number of job matches in modern labor markets are transitions from other jobs or directly from out of the labor force to employment. The former has an unambiguous theoretical interpretation: some employed workers are active job seekers. The latter is more vague. Since anyone without a job and actively searching for one is classi..ed as unemployed, the workers who move directly from out of the labor force to employment are most likely the result of inadequate measuring, due for example to the length of time between survey points. A worker previously out of the labor force may become an active searcher and get a job within a week, and so miss the classi...cation of unemployment in a monthly survey. In countries where labor force surveys are quarterly this problem can lead to large in $\neq$ ows of workers from out of the labor force to employment.

In principle there is no dic culty introducing employed job seekers in the models underlying the matching function (in theoretical work on matching, those out of the labor force who transit to employment directly do not have a separate status from the unemployed, as the period of analysis can be made suф ciently short to ensure that all those who enter employment pass ..rst from the pool of job seekers). The way in which employed job seekers enter the matching function depends on the assumptions that one makes about their search behavior and its relation to that of the unemployed job seekers (Burgess, 1993, Pissarides, 1994). For example, if employers prefer employed job seekers to the unemployed, a ranking model could be used to arrive at (3.8), but with the number of employed job seekers taking the place of the short-term unemployed in the expression and the total number of unemployed workers ranking below them in the application queue. ${ }^{15}$

\footnotetext{
${ }^{14} \mathrm{M}$ ention should also be made of the study by Lindeboom et al. (1994), who make use of the link between the aggregate matching function and hazard rate speci..cations for evaluating the relative exectiveness of alternative search channels.

${ }^{15} \mathrm{~T}$ his would bethe most appropriate framework for the analysis of "vacancy chains", whereby
} 
If, on the other hand, it is believed that the main dixerence between employed and unemployed job seekers is in the choice of search intensity or reservation wage, a function like (3.6) or (3.7) would be more appropriate. We derive the matching function (3.7) when there are employed job seekers as an illustration, under the reasonable assumption that employed job seekers have dixerent (usually higher) reservation wage than unemployed job seekers.

Let $R_{E}$ be the mean reservation wage of employed job seekers and $R_{U}$ the mean reservation wage of the unemployed. The number of unemployed seekers is as before $U$ and the number of employed job seekers $E$ : The number of job vacancies is $\mathrm{V}$ and all workers qualify for all vacancies. If the unemployed search with intensity $s$ and the employed with intensity normalized to unity, the contact technology is $m(s U+E ; V)$ and the probability that an employed worker meets a job vacancy is $m(s U+E ; V)=s U+E)$ : The probability that this vacancy is acceptable is $1_{i} G\left(R_{E}\right)$; so the hazard rate for the employed is $\left[1_{i} G\left(R_{E}\right)\right] \mathrm{m}(\mathrm{sU}+$ $E ; V) \neq(s U+E): T$ he hazard rate for the unemployed satis..es a similar expression, $\left.\left[1_{i} G\left(R_{U}\right)\right] \operatorname{sm}(s U+E ; V) \neq s U+E\right)$. Therefore, the aggregate matching function is

$$
M=\frac{\left[1 ; G\left(R_{E}\right)\right] E+\left[1 ; G\left(R_{U}\right)\right] s U}{E+s U} m(s U+E ; V):
$$

The introduction of employed job seekers opens up two empirical challenges, which are also relevant to the group of workers who in the data move directly from out of the labor force to employment. The ..rst is the need to ensure a good match between the fow variable on the left-hand side of the equation and the stock variable on the right-hand side. We have already encountered this problem when we considered the implications of the group who fow from unemployment to out of the labor force and a similar measurement problem arises for those who fow from employment and out of the labor force to employment. The second challenge is partly one of theory. It is the question whether one can regress, say, job matches from unemployment on the unemployment stock ignoring the employed job seekers and those out of the labor force. Are the estimates of the matching function elasticities obtained in this regression unbiased?

B efore suggesting ways that the literature has dealt with these two questions we summarize some evidence on the relative importance of employment in $\ddagger$ ows that do not originate in recorded unemployment. Blanchard and Diamond (1989)

the employed take the new and better vacancies ..rst, vacating jobs down the line, and the unemployed get pushed to the bottom of the vacancy chain. See Contini and Revelli (1997) and A kerlof et al. (1988). 
construct a job-to-job ¥ow series for the United States by making the assumption that these $\ddagger$ ows account for $40 \%$ of all job quits, the proportion estimated by A kerlof et al. (1988), and that the quit rate for the economy as a whole is the same as the quit rate in manufacturing. This procedure leads them to conclude that job-to-job movements account on average for $15 \%$ of total hires in the period 1968-1981. The remainder $85 \%$ is accounted for by hires from unemployment (45\%) and hires from out of the labor force (40\%).

Similar information for the United Kingdom can be derived from the $\mathrm{Em}$ ployment Audit which uses the quarterly Labour Force Survey data. J ob-to-job moves in 1992 represented $51 \%$ of total hires, while fows from unemployment and inactivity represented $21 \%$ and $27 \%$ respectively. Due to the three-month gap between observations, these data tend to overstate the importance of job-to-job moves and moves from out of the labor force (and understate those from unemployment, as many workers with less than three month unemployment durations are missed in the unemployment count). Even allowing for some correction, however, Pissarides (1994) suggests a lower bound for job-to-job moves of $40 \%$ of total hires. Elsewhere in Europe, job switches appear to be less frequent than in the United Kingdom. Burda and Wyplosz (1994) estimate that in Germany in 1987 job-to-job ¥ows represented $16 \%$ of employment in $\ddagger$ ows, with the rest being shared in equal proportions by unemployment and inactivity $\ddagger$ ows. The picture for German worker $¥$ ows is thus similar to the US picture. In France, $67 \%$ of the employment in $\ddagger$ ow was accounted for by unemployment out $\ddagger$ ows, with job-to-job ‡ows accounting for a mere $10 \%$ and $\ddagger$ ows out of inactivity for $23 \%$.

Thus both łows out of inactivity and job-to-job switches are large relative to the unemployment out $\ddagger$ ow. There is virtually no evidence on the properties of the $\ddagger$ ow from inactivity into jobs but some evidence on the properties of the job-to-job ‡ow may shed light on its in uence on the unemployment $\ddagger$ ow. W hat little evidence there is on the cyclical properties of $\ddagger$ ows in and out of inactivity gives mixed signals. Blanchard and Diamond (1989, 1990a) note that the fow of hires from out of the labor force is procyclical in the United States, while Burda and W yplosz (1994) conclude that fows in and out of the labor force do not exhibit any particular cyclical pattern in Europe. A rich body of evidence, however, con..rms that job-to-job łows are procyclical and closely linked to the quit rate.

Burgess (1993) builds a model of competition between employed and unemployed job seekers, and explains the procyclicality of job switches by modeling employed job search on the basis of a reservation wage rule. Employed workers 
whose wages fall below the (endogenous) reservation wage start searching for a better job. The reservation wage increases when the probability of receiving a job oxer is higher, so, when the frequency of job oxers rises in a boom, the employed have a stronger incentive to search, partially crowding out the unemployed from new jobs. In addition to this congestion exect, P issarides (1994) argues that during a boom employers open vacancies that are more attractive to the employed, given that their proportion in the pool of job applicants rises, and destroy jobs that employed workers quit, which are now acceptable only to the unemployed. This further enhances the procyclicality of job-to-job ‡ows. M ore recently, Boeri (1995) combines endogenous employed job search with the possibility that unemployed job search has dixerent intensities at dixerent durations.

Recent empirical work explicitly takes into account employed job search and sometimes out-of-labor-force job search. Blanchard and Diamond (1989) use alternative de..nitions of the relevant pool of searchers, allowing the unemployed and those classi..ed as inactive to be perfect substitutes up to a scalar level. They ..nd that inactive workers do not enter the matching function with a signi..cant coec cient. Following a similar procedure, Boeri (1995) ..nds that the unemployment out $\ddagger$ ow in Germany, Spain and the United K ingdom is not axected by all employed job search but only by search of those on temporary jobs or jobs that are at risk.

For the United Kingdom, Burgess (1993) and Att..eld and Burgess (1995) ..nd evidence of endogenous job competition between employed and unemployed job seekers, obtaining an elasticity of the unemployment out $¥$ ow with respect to total hires below 1 . The standard matching function in $U$ and $V$ is then re-interpreted as a reduced-form relation for the unemployment out $\neq$ ow arising from the simultaneous determination of matching and job competition between employed and unemployed job-seekers, with on-the-job search being expressed as a function of the unemployment level. Similarly, Mumford and Smith (1997) use Australian data to extend the job search competition to workers who are out of labor force, and ..nd evidence of inactive workers ranking below the unemployed, who in turn rank below the employed in the process of ...ling vacancies. No evidence of job competition is detected instead by van Ours (1995) for the Netherlands, ..nding that employed and unemployed workers mainly apply for dixerent kinds of jobs.

It would appear from the literature discussed so far that data limitations make it diф cult to ensure that the fow and stock variables in empirical matching functions refer to the same group of workers. The literature so far has not suggested a good alternative to collecting the relevant data. It has not explored the im- 
plications of omitting the job-to-job łow in a regression of the unemployment matching rate, given the well-documented procyclicality of that $\ddagger$ ow. Of course, if employed job seekers did not cause congestion for the unemployed because they applied to dixerent kinds of jobs, as van Ours's (1995) work seems to imply, that would cause no problems in the estimation of the matching function for the unemployed. But suppose instead, for the sake of illustration, that the employed and unemployed apply to the same kinds of jobs and so congestion externalities are present. The simplest matching function in this case is $\mathrm{m}(\mathrm{E}+\mathrm{U} ; \mathrm{V})$; with the notation as before. The number of matches that go to unemployed workers is, on average, a fraction $U=E+U$ ) of the total, so the matching function for unemployed workers is

$$
M_{U}=\frac{U}{E+U} m(E+U ; V):
$$

Let $m(E+U)$ in (5.2) satisfy the Cobb-D ouglas restrictions with constant returns to scale and the elasticity with respect to job seekers equal to '; a number between 0 and 1: Then (5.2) becomes, after rearranging,

$$
\ln \mathrm{M}_{\mathrm{U}}=\left(1_{\mathrm{i}}{ }^{\prime}\right) \ln \mathrm{V}_{\mathrm{i}}\left(1_{\mathrm{i}}{ }^{\prime}\right) \ln (\mathrm{E}+\mathrm{U})+\ln \mathrm{U}_{;}
$$

where constants and other terms unrelated to $\mathrm{U}$ and $\mathrm{V}$ have been omitted.

This equation is, of course, simple to estimate, provided we have data for the stock of employed job seekers. Interestingly, we need such data even if our interest is only in the unemployment $\ddagger$ ow, because of the congestion that the employed cause for the unemployed. An increase in the number of employed job seekers reduces the transition rate of the unemployed into new jobs. Yet, although equation (5.3) is of the type estimated by several authors, the number of employed job seekers, E; is not normally included among the regressors. The closest approximation to (5.3) can be found in Burgess (1993) for the United K ingdom and Mumford and Smith (1997) for A ustralia. The speci..cation estimated by Burgess regresses $\ln \left(M_{U}=U\right)$ on $\ln (M=)$ ) and $\ln (U=L)$ (where $M$ denotes total matches) and represents the reduced form equation stemming from a model of job competition between employed and unemployed job seekers, in which on-the-job search is a function of $M=\left\llcorner\right.$ and $U=L$ : M umford and Smith regress $\ln \left(M_{U}=U\right)$ on $\ln M$, $\ln U$ and $\ln (E=U)$, in which $E$ is proxied by the number of job quitters in the previous period.

To see the implications of the omission of $E$ from the list of regressors, suppose that the cycle is measured by the ratio $V=U$; the tightness of the labor market, and 
let $E=,(V=U)^{\circledR}$ : Given the responsiveness of the number of employed job seekers to the cycle, the coec cient ßis positive and likely to exceed 1: Then if a log-linear form of (5.3) is estimated with $\ln V$ and $\ln U$ as independent variables, omitting $\mathrm{E}$; the coec cients estimated are approximately the elasticities of matches, $\mathrm{M}_{U}$; with respect to $\mathrm{V}$ and $\mathrm{U}$ evaluated at sample means. Let these be ${ }^{-} \mathrm{V}$ and ${ }^{-} \mathrm{U}$ : Dixerentiation of (5.3) with $E=,(V=U)^{\circledR}$ gives,

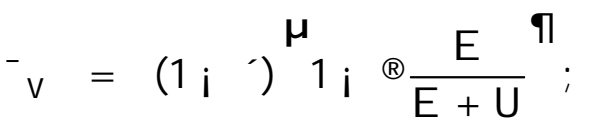

$$
\begin{aligned}
& { }^{-} u={ }^{\prime}+\left(1 i^{\prime}\right)(1+\AA) \frac{E}{E+U^{\prime}} ;
\end{aligned}
$$

with $\mathrm{E} \neq \mathrm{E}+\mathrm{U}$ ) evaluated at its sample mean.

Two implications follow from these expressions. First, the regression that omits $\mathrm{E}$ will give too low an estimate of the exect of vacancies on matchings and too high an estimate of the exect of unemployment, when compared with the underlying elasticity '. A s a corollary, if the objective is to estimate the coed cient '; the estimate obtained from the estimated ${ }^{-} \mathrm{s}$ is biased upward. This is a direct implication of the pro-cyclicality of employed job search, since if $\Theta=0$; ${ }^{-} \vee$ gives an unbiased estimate of ' $:$ Second, if the matching function satis..es constant returns, as assumed, then a test of constant returns by comparing the coed cients ${ }^{-} v$ and ${ }^{-}$; as normally done in the literature, will reject constant returns in favor of increasing returns, since,

$$
{ }^{-} v+{ }^{-} u=1+\left(1 i{ }^{\prime}\right) \frac{E}{E+U}:
$$

Conversely, if constant returns is accepted on the ${ }^{-} s$, the underlying matching function with employed job seekers included satis..es decreasing returns to scale. ${ }^{16}$

\section{Aggregation Issues}

\subsection{Time aggregation}

The matching function describes a process that takes place continually in spatially distinct locations. The use of discretetime data for arbitrary regional divisions

\footnotetext{
${ }^{16}$ Of course, it is also possible that the sum of the coet cients of both regressions fall within the con..dence interval implied by constant returns, although their point estimates may dixer in the direction pointed out.
} 
to estimate aggregate matching functions introduces both temporal and spatial aggregation problems.

Time aggregation problems arise when łow variables are estimated as functions of stock conditioning variables. This happens in the empirical production literature, where a production function is used to describe the fow of output from the stocks of inputs. Similarly, the matching function describes the łow of matches as a function of the stocks of unemployment and vacancies. In order to analyze the problems introduced by time aggregation in this case, we consider for convenience an explicit log-linear version of the matching function and introduce a well-behaved disturbance term ${ }^{2} \mathrm{t}$

$$
\ln \mathrm{M}_{\mathrm{t}}=\mathbb{B}_{\mathrm{O}}+{ }_{\mathrm{B}} \ln \mathrm{V}_{\mathrm{t}}+\mathbb{B}_{2} \ln \mathrm{U}_{\mathrm{t}}+{ }^{2} \mathrm{t}:
$$

If $M_{t}$ is measured as a fow over a time period, and $U_{t}$ and $V_{t}$ as stocks at some point during the period, $U_{t}$ and $V_{t}$ are depleted by matches $M_{t}$, and this generates a downward bias in the estimated coeф cients ${ }$ and $\mathbb{B}_{2}$. This problem is often dealt with by using beginning-of-period stocks $U_{t_{i}}$ and $V_{t_{i} 1}$ as conditioning variables or as instruments for $U_{t}$ and $V_{t}$. If there is no serial correlation in the error term, lagged stocks $U_{t_{i} 1}$ and $V_{t_{i} 1}$ are uncorrelated with ${ }^{2}$ and are therefore good instruments.

But whatever stock variable is used on the right-hand side of the equation, the dependent variable is mismeasured, being the aggregated fow over a time interval during which the stocks change. The measured out $\ddagger$ ow over some time interval does not only include the out $¥$ ow from the initial stocks, but also the out $¥$ ow from the inłow over the same interval. For periods even as short as a quarter this can give rise to a situation in which the total out $\neq$ ow during the interval exceeds the initial stock. For vacancies, whose average completed duration is in most cases under a month, even monthly data would deliver exit rates above 1.

Here we discuss this problem more formally using an exponential probability distribution of duration, characterized by constant hazard with respect to duration during the measurement period. A ssuming a hazard rate , ; the survival probability of an unemployed worker is $S(t)=\exp (i, t)$, with $t$ denoting the elapsed duration of search. The probability of being matched (the out $\neq$ ow rate) over a time period of length $t$ is therefore $F(t)=1 ; \exp (i, t)$.

Let us consider a period of unit length. Assuming an initial stock of unemployment $\mathrm{U}_{0}$, and a subsequent inłow $\mathrm{u}(\mathrm{t}), \mathrm{t} 2[0 ; 1]$, the unemployment out $\neq \mathrm{ow}$ is given by 


$$
M={ }^{3} 1 ; e^{i} \cdot U_{0}+{ }_{0}^{Z_{1} h} 1 ; e^{i \cdot\left(l_{i} t\right)^{i}} u(t) d t
$$

where the ..rst term denotes the out $\ddagger$ ow from the initial stock and the second denotes the out $\ddagger$ ow from the in $\ddagger$ ow. A symmetric expression can be computed for vacancies. Estimating (6.1) on discrete data using beginning-of-period stocks as conditioning variables therefore omits the originating stocks for the number of matches represented by the second term in (6.2).

Under the simplifying assumption of uniform in $\ddagger$ ow $u$ during the whole period, we have

$$
M={ }^{3} 1 \mathrm{i} \mathrm{e}^{\mathrm{i} \cdot} \mathrm{U}_{0}+1 \mathrm{i} \frac{1}{3}^{3} 1 \mathrm{i} \mathrm{e}^{\mathrm{i}} \cdot{ }^{\prime} \mathrm{u}:
$$

It can be noted that the term in square brackets is bounded between zero and one, and therefore describes a plausible out $\ddagger$ ow rate from the in $\ddagger$ ow. Also the out $\neq$ ow rate from the in $\neq$ ow is lower than the one from the stock, for the reason that the in $\ddagger$ ow has, on average, less time available for a successful match.

In order to take into account the matches generated by in $\ddagger$ ows $u$ and $v$, righthand side variables in (6.1) should include the beginning-of-period stock, plus some proportion of ${ }_{3}$ the in $\ddagger$ ow. Given that each agent in $U_{0}$ has a matching probability which is $1 \mathrm{i}$ ei ${ }^{i}{ }^{i}{ }^{1}$ times the matching probability of each agent in $u$, the pool of unemployed job seekers between time 0 and time 1 can be expressed in homogeneous "search units" as

$$
\mathrm{U}_{0}+{ }^{3} 1 \mathrm{i} \mathrm{e}^{\mathrm{i}}{ }^{\prime} \mathrm{i}^{1} \mathrm{i} \underline{1}^{\circ} \mathrm{u} \text {; }
$$

and similarly for vacancies. In order to compute the expression in (6.4), the hazard rate, can be obtained by estimating equation (6.3) on stocks and $\ddagger$ ows. Alternatively, for small enough,; the term in square brackets in (6.4) can be approximated by $1=2$, using a second order Taylor expansion of $\exp (i$,$) around$ , 0 :

Gregg and Petrongolo (1997) follow the latter procedure in order to deal with the time aggregation problem in the estimation of an aggregate matching function for Britain for the period 1967-1995. Their analysis combines this treatment of time aggregation with a stock- $¥$ ow matching mechanism (see Section 3.5). The resulting matching function estimates suggest that there has been no deterioration in the matching exectiveness of vacancies over the period considered. There seems instead to have been some fall in the matching exectiveness of the unemployed, 
although less severe than that implied by the conventional stock-based analysis of matching (namely, the in $¥$ uence of the time trend of aggregate studies is reduced).

Berman (1997) uses instead the sum of beginning-of-period stocks and subsequent łows to construct a proper instrument for $U_{t}$ and $V_{t}$ in estimating a log-linear referral function for Israel over the period 1978-1990. IV estimation delivers higher elasticities of referrals with respect to unemployment and vacancies than OLS estimation, detecting a downward (simultaneity) bias in OLS estimates.

An alternative way of ensuring matching probabilities strictly bounded between 0 and 1; proposed by den Haan et al. (1997), departs from the standard log-linear speci..cation (6.1). They consider that matching takes place when a ..rm and a worker meet through a pair-speci..c channel. There are $\mathrm{J} t$ channels in the economy, and each agent is randomly assigned to one of them. With this procedure, a worker locates a vacancy with probability $V_{t} A_{t}$, and a ..rm locates a worker with probability $\mathrm{U}_{\mathrm{t}} \mathrm{J}_{\mathrm{t}}$ : M atches are given by $\mathrm{M}_{\mathrm{t}}=\mathrm{U}_{\mathrm{t}} \mathrm{V}_{\mathrm{t}} \mathrm{A}_{\mathrm{t}}$. The properties of this matching function depend on the speci...cation of $\mathrm{J}$. The speci..cation adopted by the authors is $\mathrm{J}_{\mathrm{t}}=\mathrm{U}_{\mathrm{t}}^{1}+\mathrm{V}_{\mathrm{t}}^{1}{ }^{1 \neq}$, which restricts exit rates of unemployment and vacancies between 0 and 1 , as I goes from 0 to 1 : den Haan et al. use these functions in a dynamic general equilibrium model with productivity shocks. The calibration of their model delivers a close match with data on labor market fows when the parameter I is set equal to 1:27:

Going back to empirics, Burdett et al. (1994) show that the use of beginningof-period stocks as sole conditioning variables generates a bias in the resulting elasticities of $M_{t}$ with respect to $U_{t_{i} 1}$ and $V_{t_{i} 1}$ that depends on the time series properties of the two stocks. Suppose that both $U_{t_{i} 1}$ and $V_{t_{i} 1}$ are mean-reverting series, an assumption which is implicit in a matching function where the number of matches is a positive function of $\mathrm{U}_{\mathrm{t}_{1} 1}$ and $\mathrm{V}_{\mathrm{t}_{1} 1}$. In this case the average size of a stock over a time period tends to be negatively correlated with the size at the beginning of the period. This implies that, when unemployment (or the number of vacancies) is above the mean, the average size of the stock during the following period will be smaller, depleting the number of aggregate matches during the period. On the other hand, when the initial stock is below the mean, its size tends to increase afterwards, generating a higher number of intra-period matches. This mechanism generates a downward bias in the estimated elasticities of $M_{t}$ with respect to $U_{t_{i} 1}$ and $V_{t_{i} 1}$ :

It is shown however that, for a small enough measuring interval, the size of the bias is approximately a linear function of its length. Thus the size of the bias can be estimated by doubling the length of the measuring interval and comparing 
the obtained coet cients with those estimated using the original data frequency. This procedure, applied by Burdett et al. to the data used by Blanchard and Diamond, suggests that the bias is not important whenever the data frequency is monthly or higher and the cycle frequency is yearly or higher.

\subsection{Spatial aggregation}

The other issue that links aggregate production and matching technologies is aggregation across space. As in the empirical production literature, most authors of empirical matching functions aggregate the number of unemployed workers and job vacancies across space and use the aggregates to explain the $\ddagger$ ow of job matches in the same space. This practice treats the aggregate economy as a single labor market, ignoring the fact that it might be a collection of spatially distinct labor markets with possibly little interaction. The relevant issue is whether aggregating local labor market data biases the resulting estimates.

Coles and Smith (1996) argue that spatial aggregation might bias the results towards constant returns to scale in the matching function, while the matching process could display increasing returns instead. The underlying intuition is that replicating a marketplace of a given size and with a given number of searchers should double the number of matches if there is no interaction between the two marketplaces. But if there is interaction, the number of matches more than doubles, because cross-border matches can now be formed. So with interactions between markets, matches more than double when the number of searchers doubles within the original marketplace, implying increasing returns to scale. Since interactions are likely to be more common in more dense markets, Coles and Smith conclude that in estimation density is likely to be more important than market size, something for which they ..nd evidence in their study. Indeed they ..nd constant returns to scale on average but with more dense markets delivering higher matching rates for given size of the vacancy and unemployment pools.

Constant returns to scale are also not rejected in a similar study by Bennet and Pinto (1994), who estimate separate local matching functions over the period 1985-1991 for 104 areas of Training and Enterprise Councils that cover Britain. They ..nd that most of the estimates for the returns to scale range between 0.7 and 1.15 .

A further issue concerns the interaction between local matching and regional migration or commuting behavior. The importance of job search considerations in worker migration is recognized by J ackman and Savouri (1992). They note that 
the direction of gross migration $¥$ ows in Britain is consistent with a job search approach, in which migration is interpreted as the outcome of job matching. The magnitude of migration $¥$ ows is best explained in time series regressions by the evolution of the total number of job-worker matches. Regional migration facts are instead diф cult to reconcile with the predictions of competitive human capital theory, mainly on the grounds that high wage regions do not seem to attract signi...cant migration $\ddagger$ ows.

The exects of regional migration and commuting on local matching conditions are analyzed by Burda and Pro..t (1996). They represent an aggregate economy as a two-dimensional space divided into a number of districts. Workers' decisions determine search intensity in all districts, namely how many jobs to apply for in each district. This extension of the matching function to the spatial dimension relates job matching in a district to economic conditions everywhere in the economy, inducing a network of complex spillover exects between neighboring districts. Burda and Pro..t estimate a matching function that embodies regional spillovers for 76 Czech labor market districts, and ..nd signi..cant exects of neighboring unemployment on local matching. Constant returns to scale in the matching function cannot be rejected. This speci..cation is also used by Burgess and Pro..t (1998) in order to study local matching and spillovers in 303 B ritish travel-to-work areas. They ...nd that more unemployed job-seekers (vacancies) in neighboring areas raise the local vacancy (unemployment) out $\ddagger$ ow but lower the local unemployment (vacancy) outłow.

A long similar lines, Petrongolo and Wasmer (1999) estimate a matching function for Britain (1986-1995) and France (1983-1994), using a regional panel for each country. Cross-regional spillovers are considered, allowing each worker to search in her own and other regions with dixerent search intensities. It is found that search intensity is positive and signi..cant in regions that are adjacent to the one where the worker lives, although it is only about $10 \%$ of the level of search intensity in the region of residence. Constant returns to scale in the matching function are not rejected by either the B ritish or the French data, in contrast to the aggregate study for France in Table 3, which found decreasing returns.

In conclusion, although the problem of spatial aggregation has only recently been discussed in the estimation of matching functions, the ..ndings of those who explicitly embody a spatial dimension into the estimation do not invalidate earlier results on aggregate matching functions. Their analysis, however, sheds more light on the regional dimensions of job matching and the spillovers between regions. 


\section{Conclusions}

Like most other aggregate functions in the macroeconomist's tool kit, the matching function is a black box: we have good intuition about its existence and properties but only some tentative ideas about its microfoundations. Y et, those tentative ideas have not been rigorously tested. They have been used only to provide justi..cation for the inclusion or exclusion of variables from the estimation of aggregate or regional matching functions, leaving it to the empirical speci..cation to come up with a convincing functional form.

The early aggregate studies converged on a Cobb-Douglas matching function with the $\ddagger$ ow of hires on the left-hand side and the stock of unemployment and job vacancies on the right-hand side, satisfying constant returns to scale, and with the coec cient on unemployment in the range 0.5-0.7. In some of the estimates that use total hires as dependent variable (not only hires from unemployment) the coed cient on unemployment is lower, in the range $0.3-0.4$, and the coet cient on vacancies correspondingly higher. But estimation of both Beveridge curves and aggregate matching functions points also to other variables that in $\ddagger$ uence the simple Cobb-D ouglas relationship. Much of the estimation of matching functions in the last decade has looked for those other variables and for better empirical speci..cations. Micro studies suggest as additional variables the age structure of the labor force, the geographical dispersion of job vacancies and unemployed workers, the incidence of long-term unemployment (exceeding one year), and unemployment insurance; interestingly, however, although the other variables have been found signi..cant where tested, unemployment insurance has not been identi..ed as a signi..cant inłuence on aggregate matching rates. We have argued that this may be related to measurement problems and the diфculty of getting a reliable time series for the generosity of unemployment insurance systems.

Recent empirical work has used disaggregate data and modeled the micro matching functions more carefully, paying attention to the issue of consistency between the timing of the fows and the timing of the stocks in the regressions, the regional spillovers in matching, and the consistency between the fow and stock variables, given the observation that many matches involve either employed workers or workers classi..ed as out of the labor force. The precision of the estimation has increased and the relation between hazard function estimation and aggregate matching function estimation has become clearer. It has been found that aggregation problems have played a role in some of the shifts in the aggregate matching function, though not to an extent that can render the aggregate 
function "unstable". Despite all the re. nements and detailed tests, the ..ndings of the ..rst aggregate studies have not been challenged: the stable, constant returns aggregate function used in macroeconomic modeling ...nds strong support in the data of virtually all modern economies where tests have been conducted.

Future work needs to elaborate a number of issues. The search for microfoundations needs to continue, and rigorous tests of plausible alternatives done. Good microfoundations can aid the estimation of structural coed cients, which are used in model calibrations and policy analysis. Currently, the most popular functional form, Cobb-D ouglas with constant returns to scale, is driven by its empirical success and lacks microfoundations. The most popular microeconomic models, such as the urn-ball game, do not perform as well empirically. Yet, dixerent microeconomic matching mechanisms have dixerent implications for wage determination and other types of behavior in markets with frictions and can help in the design of optimal policy toward unemployment and inequality.

On the empirical side, on-the-job search and search out of the labor force need to be more car efully measured and their implications for unemployed search and matching studied. The meaning of constant returns also needs to be studied further. Although constant returns in the numbers involved in matching are supported, there have been no rigorous tests of the plausible property that the quality of matches is better in larger markets, on the grounds that participants have more choices. This may be more true in skilled labor markets, where skill heterogeneities are more likely to matter, opening up the possibility of dixerent matching technologies for dixerent types of skill.

\section{R eferences}

[1] A braham, K. (1987), “Help Wanted A dvertising, J ob Vacancies and Unemployment." Brookings Papers on Economic Activity, 1, 207-243.

[2] Abraham, K. and L. Katz (1986), "Cyclical Unemployment: Sectoral Shifts or Aggregate Disturbances?" J ournal of Political Economy, 94, 507-522.

[3] Acemoglu, D. and R. Shimer (2000). "Wage and Technology Dispersion." Review of Economic Studies 67.

[4] A kerlof, G., A. Rose and J . Y ellen (1988), "J ob Switching and J ob Satisfaction in the U.S. Labor M arket." B rookings Papers on Economic Activity, 2, 495-582. 
[5] Anderson, P. and S. Burgess (2000), "Empirical Matching Functions: Estimation and Interpretation Using Disaggregate Data." Review of E conomics and Statistics 82, 93-102.

[6] Andolfatto, D. (1996). "Business Cycles and Labor Market Search." American Economic Review 86, 112-132.

[7] Atkinson, A. B., J. Gomulka, J. Micklewright and N. Rau (1984), "Unemployment Bene..t, Duration and Incentives in Britain." J ournal of Public Economics, 23, 3-26.

[8] Att..eld, C. and S. Burgess (1995), "J ob Matching, J ob Competition and Vacancies in the UK." University of Bristol, mimeo.

[9] Bell, U.L. (1997), "A Comparatice A nalysis of the A ggregate M atching P rocess in France, Great Britain and Spain." Banco de España - Servicio de Estudios, Documento de Trabajo No. 9721.

[10] Bennet, R. and R. Pinto (1994), "The Hiring Function in Local Labour Markets in Britain." Environment and Planning, 26, 1957-1974.

[11] Bentolila, S. and J. Dolado (1991) "Mismatch and Internal Migration in Spain, 1962-1986." In F. Padoa Schioppa (ed.), Mismatch and Labour Mobility, Cambridge: Cambridge University P ress.

[12] Berman, E. (1997), "Help Wanted, J ob Needed: Estimates of a Matching Function from Employment Service Data." J ournal of Labor E conomics, 15, 251-291.

[13] Blanchard, O. and P. Diamond (1989), "The Beveridge Curve." Brookings Papers on Economic Activity, 1, 1-76.

[14] Blanchard, O. J . and P. A. Diamond (1990a), "The Cyclical Behavior of Gross F lows of U.S. Workers." B rookings Papers on Economic Activity, 2, 85-155.

[15] Blanchard, O. J . and P. A. Diamond (1990b), "T he Aggregate Matching Function." In Diamond, P. (ed.), Growth, Productivity and Unemployment, Cambridge MA: The MIT Press. 
[16] Blanchard, O. J . and P. A. Diamond (1994), "Ranking, Unemployment Duration and Wages." The Review of Economic Studies, 61, 417-434.

[17] Bleakley, H. and J. Fuhrer (1997), "Shifts in the Beveridge Curve, J ob Matching, and Labor Market Dynamics." New England Economic Review 0(9), 3-19.

[18] Boeri, T . (1995), "On-the-J ob Search and Unemployment Duration." European University Institute Working Paper No. 38.

[19] Boeri, T. and M. Burda (1996), "Central and Eastern European Labour Markets: Active Labour Market Policies, J ob Matching and the Czech M iracle." European E conomic Review, 40, 805-817.

[20] Bowden, R. J . (1980), "On the Existence and Secular Stability of the u-v Loci." E conomica, 47, 35-50.

[21] Brunello, G. (1991), "Mismatch in J apan." In F. Padoa Schioppa (ed.), Mismatch and Labour Mobility, Cambridge: Cambridge University Press.

[22] Budd, A., P. Levine and P. Smith (1988), "Unemployment, Vacancies and the Long-Term Unemployed." The Economic J ournal, 98, 1071-1091.

[23] Burda, M . (1993), "Unemployment, Labour Markets and Structural Change in Eastern Europe." E conomic Policy 16, 101-137.

[24] Burda, M. and S. Pro..t (1996), "Matching across Space: Evidence on M obility in the Czech Republic." Labour Economics, 3, 255-278.

[25] Burda, M. and C. Wyplosz (1994), "Gross Worker and J ob Flows in Europe." European E conomic Review, 38, 1287-1315.

[26] Burdett, K. and K. J udd (1983). "Equilibrium Price Distributions." E conometrica 51, 955-970.

[27] Burdett, K., M. Coles and J . van Ours (1994), "Temporal Aggregation Bias in Stock-Flow Models." CEPR Discussion Paper No. 967.

[28] Burdett, K. and E. Cunningham (1998), "Towards a Theory of Vacancies." J ournal of Labor E conomics, 16, 445-478. 
[29] Burdett, K. and D. Mortensen (1998), "Wage Dixerentials, Employer Size, and Unemployment." International E conomic Review, 39, 257-273.

[30] Burgess. S. (1993), "A Model of Competition between Unemployed and Employed J ob-Searchers: An Application to the Unemployment Outłow Rate in Britain." The Economic J ournal, 103, 1190-1204.

[31] Burgess. S. and S. Pro..t (1998), "Externalities in the Matching of Workers and Firms in Britain." CEPR Discussion Paper No. 1854.

[32] Butters, G. (1977), "Equilibrium Distributions of Sales and Advertising Prices." Review of Economic Studies, 44, 465-491.

[33] Clark, K. and L. Summers (1979), "Labor Market Dynamics and Unemployment: A Reconsideration." Brookings Papers on Economic Activity, 1, 13-60.

[34] Coles, M. (1994), "Understanding the Matching Function: The Role of Newspapers and J ob Agencies." CEPR Discussion Paper No. 939.

[35] Coles, M. (1999), "Turnover Externalities with Marketplace Trading." International Economic Review, 40, 851-868.

[36] Coles, M. and E. Smith (1996), "Cross-Section Estimation of the Matching Function: Evidence from England and Wales." Economica, 63, 589-598.

[37] Coles, M . and E. Smith (1998), "M arketplaces and M atching." International Economic Review, 39, 239-254.

[38] Contini, B., L. Pacelli, M. Filippi, G. Lioni and R. Revelli (1995). A Study of J ob Creation and J ob Destruction in Europe. Brussels: Commission of the European Communities (..le soc 94-1023318-05003 - item B34010).

[39] Contini, B. and R. Revellli (1997), "Gross Flows vs. Net Flows in the Labor Market: What is There to be Learned?" Labour E conomics, 4, 245-263.

[40] Cooper, R. W . and A. J ohn (1988). "Coordinating Coordination Failures in Keynesian M odels." Quarterly J ournal of Economics 103, 441-463.

[41] Davis, S., J. Haltiwanger and S. Schuh (1996), J ob Creation and Destruction, Cambridge: MIT Press. 
[42] Devine, T. and N. Kiefer (1991), Empirical Labor Economics: The Search A pproach, Oxford: Oxford University Press.

[43] Diamond, P. A. (1971), "A Model of Price Adjustment." J ournal of Economic Theory 3, 156-168.

[44] Diamond, P. A . (1982a), “Aggregate Demand Management in Search Equilibrium." J ournal of Political E conomy, 90, 881-894.

[45] Diamond, P. A. (1982b), "Wage Determination and E $\$$ ciency in Search Equilibrium." Review of Economic Studies, 49, 217-227.

[46] Diamond, P. A. (1984). "M oney in Search Equilibrium." Econometrica 52, $1-20$.

[47] Diamond, P. A . and E. Maskin (1979). "An Equilibrium A nalysis of Search and B reach of Contract." Bell J ournal of Economics, 10, 282-316.

[48] Dow, J. C. R. and L. A. Dicks-Mireaux (1958). "The Excess Demand for Labour: A Study of Conditions in G reat B ritain, 1946-56." Oxford Economic Papers, 10, 1-33.

[49] Drèze, J . and C. Bean (1990), "E urope's Unemployment Problem: Introduction and Synthesis." In J. Drèze and C. B ean (eds.), European Unemployment: Lessons from a Multy-Country Econometric Study, Cambridge MA: The MIT Press.

[50] Dunne, T., M. Roberts and L. Samuelson (1989), "Plant Turnover and Gross Employment Flows in the U.S. Manufacturing Sector." J ournal of Labor E conomics, 7, 48-71.

[51] Eckstein, Z. and K. Wolpin (1995), "Duration to First J ob and the Return to Schooling: Estimates from a Search-Matching Model." The Review of Economic Studies, 62, 263-287.

[52] E din, P. and B. Holmlund (1991), "Unemployment, Vacancies and Labour Market Programmes: Swedish Evidence." In F. Padoa Schioppa (ed.), Mismatch and Labour Mobility, Cambridge: Cambridge University P ress.

[53] Entorf, H. (1998), Mismatch Explanations of European Unemployment: A Critical Evaluation, Heidelberg and New York: Springer. 
[54] Feldstein, M.S. (1973). Lowering the Permanent Rate of Unemployment. A study prepared for the use of the J oint Economic Committee, 93 Cong. 1 sess.

[55] Fêve, P. and F. Langot (1996), "Unemployment and the B usiness Cycle in a Small Open Economy: G.M.M. Estimation and Testing with French Data." J ournal of Economic Dynamics and Control, 20, 1609-1639.

[56] Flinn, C. and J. Heckman (1982), "New Methods for A nalyzing Structural Models of Labor Force Dynamics." J ournal of E conometrics, 18, 115-168.

[57] Franz, W. (1991), "Match and Mismatch on the German Labour Market." In F. Padoa Schioppa (ed.), Mismatch and Labour Mobility, Cambridge: Cambridge University Press.

[58] Friedman, M. (1968), "T he R ole of M onetary Policy." A merican Economic Review, 58, 1-17.

[59] Gregg, P. and B. Petrongolo (1997), "Random or Non-random M atching? Implications for the Use of the UV Curve as a M easure of Matching Exectiveness." Institute for Economics and Statistics (Oxford) Discussion Paper No. 13.

[60] Gross, D. (1997), "A ggregate J ob Matching and Returns to Scale in Germany." Economic Letters, 56, 243-248.

[61] Guilkey, D., C. Lovell and R. Sickles (1983), "A Comparison of the Performance of Three Flexible Functional Forms." International E conomic Review, 24, 591-616.

[62] Haan, den W., G. Ramey and J. Watson (1997), "J ob Destruction and the Propagation of Shocks." University of California, San Diego, Discussion Paper No. 97-23.

[63] Hall, R. (1972), "Turnover in the Labor Force." Brookings Papers on Economic Activity, 3, 709-756.

[64] Hall, R. (1979), "A Theory of the Natural Unemployment Rate and the Duration of Employment." J ournal of M onetary E conomics, 5, 153-169. 
[65] Hansen, B. (1970), "Excess Demand, Unemployment, Vacancies, and Wages." Quarterly J ournal of E conomics, 84, 1-23.

[66] Hicks, J . (1932, 1963), The Theory of Wages, London: M acmillan.

[67] Holt, C. C. (1970a). "J ob Search, Phillips' Wage Relation, and Union In¥uence." In The Microeconomic Foundations of Employment and In‡ation Theory, edited by E. S. P helps et al. New York: Norton.

[68] Holt, C. C. (1970b). "How Can the Phillips Curve Be Moved to Reduce Both Infation and Unemployment?" In The Microeconomic Foundations of Employment and In ation Theory, edited by E. S. Phelps et al. N ew York: Norton.

[69] Howitt, P. and R. P. M cA fee (1987). "Costly Search and Recruiting." International Economic Review 28, 89-107.

[70] Hutt, W. (1939), The Theory of Idle Resources, London: J onathan Cape.

[71] Ioannides, Y. M. (1997). "Evolution of Trading Structures." In The Economy as an Evolving Complex System II, edited by W. B. Arthur, S. N. Durlauf and D. A. Lane. Reading, M A: Addison-Wesley.

[72] J ackman, R., R. Layard and C. A . P issarides (1989), "On Vacancies." Oxford Bulletin of Economics and Statistics, 51, 377-394.

[73] J ackman, R., C. A. Pissarides and S. Savouri (1990). "Labour M arket Policies and Unemployment in the OECD." E conomic Policy 11, 449-490.

[74] J ackman, R. and S. Roper (1987), "Structural Unemployment." Oxford B ulletin of E conomics and Statistics, 49, 9-36.

[75] J ackman, R. and S. Savouri (1992), "Regional Migration in Britain: An A nalysis of G ross F lows U sing NHS Central Register Data." The Economic J ournal, 102, 1433-1450.

[76] J ovanovic, B. (1979), "J ob M atching and the Theory of Turnover." J ournal of Political Economy, 87, 972-990.

[77] Keynes, J.M. (1936), The General Theory of Employment, Interest and Money, London: Macmillan. 
[78] Kiefer, N. and G. Neumann (1979a), "An Empirical J ob Search M odel with a Test of the Constant Reservation Wage Hypothesis." J ournal of Political Economy, 87, 89-107.

[79] Kiefer, N. and G. Neumann (1979b), "Estimation of Wage Oxer Distributions and Reservation Wages." In S. Lippman and J . M cCall (eds.), Studies in the E conomics of Search, 171-190, North Holland, New York.

[80] K iefer, N. and G. Neumann (1981), "Individual exects in a Nonlinear M odel: Explicit Treatment of Heterogeneity in the Empirical J ob Search Model." E conometrica, 49, 965-979.

[81] Kiyotaki, N. and R. Wright (1989). "On M oney as a M edium of Exchange." J ournal of Political E conomy 97, 927-954.

[82] Lagos, R. (1997), "An Alternative Approach to Market Frictions: An Application to the Market for Taxicab Rides." Unpublished paper, London School of E conomics. forthcoming in the J ournal of Polictical E conomy.

[83] Lagos, R. and G. L. Violante (1998). "W hat Shifts the Beveridge Curve? A Microfoundation for the Aggregate Matching Function." Unpublished paper, London School of E conomics.

[84] Lambert, J . (1988), Disequilibrium Macroeconomic Models: Theory and Estimation of Rationing Models Using Business Survey Data, Cambridge: Cambridge University Press.

[85] Lancaster, T. (1979). "E conometric M odels for the Duration of Unemployment." E conometrica 47, 939-956.

[86] Lang, K. (1991). "Persistent Wage Dispersion and Involuntary Unemployment." Quarterly J ournal of Economics 106, 181-202.

[87] Layard, R., S. Nickell and R. J ackman (1991), Unemployment. Macroeconomic Performance and the Labour Market, Oxford: Oxford University Press.

[88] Leonard, J . (1987), "In the Wrong Place at the Wrong Time: The Extent of Frictional and Structural Unemployment." In K. Lang and L. Leonard (eds.) Unemployment and the Structure of Labor Markets, New York: Basil Blackwell. 
[89] Lilien, D. (1982), "Sectoral Shifts and Cyclical Unemployment." J ournal of Political Economy, 90, 777-793.

[90] Lindeboom, M., J. van Ours and G. Renes (1994), "Matching Employers and Workers: An Empirical Analysis on the Exectiveness of Search." Oxford Economic Papers, 46, 45-67.

[91] Lucas, R. and E. Prescott (1974), "Equilibrium Search and Unemployment." J ournal of E conomic Theory, 7, 188-209.

[92] Manacorda, M. and B. Petrongolo (1999), "Skill Mismatch and Unemployment in OECD Countries." Economica, 66, 181-207.

[93] Marston (1976), "E mployment Instability and High Unemployment Rates." B rookings Papers on Economic Activity, 76, 169-203.

[94] M erz, M. (1995). "Search in the Labor M arket and the Real Business Cycle." J ournal of Monetary E conomics 36, 269-300.

[95] Montgomery, J . (1991). "Equilibrium Wage Dispersion and Interindustry Wage Dixerentials." Quarterly J ournal of E conomics 106, 163-179.

[96] M ortensen, D. T. (1970). "A Theory of Wage and Employment Dynamics." In The Microeconomic Foundations of Employment and In ation Theory, by E. S. Phelps et al. New York: Norton.

[97] Mortensen, D. T. (1982a), "The Matching Process as a NonCooperative/ Bargaining Game." In The E conomics of Information and Uncertainty, edited by J . J . McCall. Chicago: University of Chicago Press.

[98] M ortensen, D. T. (1982b). "Property Rights and $E \phi$ ciency in M ating, Racing, and Related Games." American Economic Review, 72, 968-979.

[99] M ortensen, D. T . (1986). "J ob Search and Labor Market A nalysis." In Handbook of Labor Economics, edited by O. C. A shenfelter and R. Layard. Amsterdam: North-Holland.

[100] Mortensen, D. T. and C. A. Pissarides (1999a). "New Developments in Models of Search in the Labor Market." In Handbook of Labor Economics, edited by 0 . A shenfelter and D. Card. A msterdam: North-Holland. 
[101] M ortensen, D. T . and C. A . P issarides (1999b). "J ob R eallocation, E mployment Fluctuations, and Unemployment." In Handbook of Macroeconomics, edited by M. Woodford and J. Taylor. A msterdam: North-Holland.

[102] Mumford, K. and P. Smith (1999), "The Hiring Function Reconsidered: On Closing the Circle." Oxford Bulletin of Economics and Statistics, 61, 343-364.

[103] Narendranathan, W. and S. Nickell (1985), "Modelling the Process of J ob Search." J ournal of E conometrics, 28, 29-49.

[104] Narendranathan, W., S. Nickell and J . Stern (1985), "Unemployment B ene.ts Revisited." The E conomic J ournal, 95, 307-329.

[105] Nickell, S. (1979), "Estimating the Probability of Leaving Unemployment." E conometrica, 47, 1249-1266.

[106] OECD (1994). The OECD J obs Study. Paris: OECD.

[107] OECD (1999). Implementing the OECD J obs Strategy: A ssessing Performance and Policy. Paris: OECD.

[108] van Ours, J . (1991), "T he E $\$$ ciency of the Dutch Labour M arket in M atching Unemployment and Vacancies." De Economist, 139, 358-378.

[109] van Ours, J . and G. Ridder (1992), "Vacancies and the Recruitment of New Employees." J ournal of Labor E conomics, 10,138-155.

[110] van Ours, J . and G. Ridder (1993), "Vacancy Durations: Search or Selection?" The Oxford Bulletin of Economics and Statistics, 55, 187-197.

[111] van Ours, J . (1995), "An Empirical Note on E mployed and Unemployed J ob Search." E conomic Letters, 49, 447-452.

[112] Petrongolo, B. (2000), "Re-Employment Probabilities and Returns to Matching." Forthcoming in the J ournal of Labor Economics.

[113] Petrongolo, B. and E. Wasmer (1999), "J ob Matching and Regional Spillovers in Britain and France." Forthcoming in M. Catin, J. Lesieur and Y. Zenou (eds.), Developments Récents et É conomie Spatiale: Employ, Concurrence Spatiale et Dynamiques Régionales, Paris: Economica. 
[114] Phelps. E. S. (1967), "P hillips Curves, Expectations of In‡ation and Optimal Unemployment over Time." Economica, 34, 254-296.

[115] Phelps, E. S. (1968). “M oney-Wage Dynamics and Labor-Market Equilibrium." J ournal of Political E conomy 76, 678-711.

[116] Phelps. E. S. et al. (1970), Microeconomic Foundations of Employment and Infation Theory, Norton, New York.

[117] Phelps. E. S. (1994), Structural Slumps: The Modern Equilibrium Theory of Unemployment, Interest, and Assets, Cambridge, Mass : Harvard University Press.

[118] Pigou, A. C. (undated) Theory of Unemployment

[119] Pissarides, C. A . (1979), "J ob Matchings with State Employment Agencies and Random Search." E conomic J ournal, 89, 818-833.

[120] Pissarides, C. A . (1984). "Search Intensity, J ob A dvertising and E $₫$ ciency." J ournal of Labor Economics 2, 128-143.

[121] Pissarides, C. A . (1985). "Short-R un Equilibrium Dynamics of Unemployment, Vacancies, and Real Wages." A merican Economic Review 75, 676-690.

[122] Pissarides, C. A. (1986), "Unemployment and Vacancies in Britain." Economic Policy, 75, 676-690.

[123] Pissarides, C. A . (1994), "Search Unemployment with On-theJ ob Search." The Review of Economic Studies, 61, 457-475.

[124] Pissarides, C. A. (1999), "Policy Inłuences on Unemployment: The European Experience." Scottish J ournal of Political Economy 46, 389-418.

[125] Pissarides, C. A. (2000), Equilibrium Unemployment Theory, Second edition, Cambridge, MA: MIT Press (..rst edition, 1990, Oxford: Blackwell)

[126] Pro..t, S. (1997), "Twin Peaks in Regional Unemployment and Returns to Scale in J ob-Matching in the Czech Republic." Quanti..kation and Simulation Ökonomischer Prezesse, Humboldt-Universität zu Berlin, Discussion Paper No. 63-1997. 
[127] Pro..t, S. and S. Sperlich (1998), "Non-U niformity of J ob-Matching in a Transition Economy - A Non-Parametric Analysis for the Czech Republic." Quanti..kation and Simulation Ökonomischer Prezesse, HumboldtUniversität zu Berlin, Discussion Paper No. 15-1998.

[128] Rothschild, M. (1973). "M odels of M arket Organization with Imperfect Information: A Survey." J ournal of Political Economy, 81, 1283-1308.

[129] Salop, S. C. (1979). "A Model of the Natural Rate of Unemployment." American Economic Review 69, 117-125.

[130] Wall, H. and G. Zoega (1997), "T he B ritish Beveridge Curve: A Tale of Ten Regions." CEPR Discussion Paper No. 1771.

[131] Warren, R. (1996), "Returns to Scale in a Matching Model of the Labour Market." E conomic Letters, 50, 135-142.

[132] Wolpin, K. (1987), "Estimating a Structural Search Model: The Transition from School to Work." Econometrica, 55, 801-818.

[133] Yashiv, E. (2000), "The Determinants of Equilibrium Unemployment." American Economic Review, forthcoming.

\section{A ppendix: Some History}

What is the history of the matching function and how did labor economists deal with frictions before the recent vintage of models?

Early writers on the economics of labor markets were aware of the importance of frictions but were unable to bring them into their formal models. Hicks (1932) in the Theory of Wages devoted a chapter to unemployment. After introducing the "commonplace" de..nitions of unemployment, he made the claim that some kinds of unemployment induce wage changes and some do not; the ones that do not are "consistent with constant supply and demand for labor" and they make up "normal unemployment". An important reason for the existence of normal unemployment, which is close to Phelps's (1967) and Friedman's (1968) equilibrium or "natural" unemployment, is the fact that

although the industry as a whole is stationary, some ..rms in it will be closing down or contracting their sphere of operations, others will 
be arising or expanding to take their place. Some ..rms, then, will be dismissing, others taking on labor; and when they are not situated close together, so that knowledge of opportunities is imperfect, and transference is attended by all the diф culties of ..nding housing accommodation, and the uprooting and transplanting of social ties, it is not surprising that an interval of time elapses between dismissal and re-engagement, during which the workman is unemployed. (Hicks, 1963, p.45).

Moreover, he claimed that these costs, the frictions, are important in determining equilibrium wages, because they imply a range of indeterminacy due to monopoly rents. But more importantly, frictions according to Hicks (1963, chapter 4), slow down the response of (real) wages to shocks and so are a major cause of short-run disequilibrium in the labor market.

Hutt (1939) also emphasized the importance of frictions in modern labor markets. In his Theory of I dle Resources he attempted to distinguish various supplyside reasons for unemployment, in the hope that they would be brought into the demand-side models of Keynes and others. A mongst them he included workers who are "actively searching for work" because they "judge that the search for a better opening is worth the risk of immediately foregone income". He then argued that such individuals should not be counted as unemployed because they are working on their own account and doing the job that an employment agency would do "if the course of politics had allowed such an institution to emerge in modern society" (Hutt, 1939, p. 60). Ironically, these individuals are the only ones counted as unemployed according to modern de..nitions.

Hutt's plea to his contemporaries to take into account such causes of unemployment was ignored. The dominant view of unemployment that emerged out of the depression of the 1930s was K eynes's view that the unemployment that Hicks called "normal" could be ignored. Keynes $(1936$, p.6) de..ned some kinds of unemployment as compatible with "full employment" and uninteresting from his point of view, along similar lines to Hicks (1932) (though without crediting him). He called these kinds "frictional" - probably the ..rst use of the term - and "between jobs", due to "various inexactness of adjustment which stand in the way of full employment". He also included "voluntary" unemployment to the kinds compatible with full employment. He credited Pigou (undated) for the best exposition of the "classical" view but criticized him for concentrating on real factors only and for claiming that only "frictional" unemployment will exist in equilibrium, and therefore "such unemployment as exists at any time is due wholly to the fact 
that changes in demand conditions are continually taking place and that frictional resistances prevent the appropriate wage adjustments from being made instantaneously" (Pigou's words, quoted by Keynes, 1936, p. 278). Thus, like Hicks, Pigou blamed frictions mainly for slow (real) wage adjustments, a point which K eynes considered irrelevant, if not erroneous (K eynes, 1936, p.278), to the point that he called the title of Pigou's book, Theory of Unemployment, "something of a misnomer" (p.275).

Keynes's followers replaced the slow real adjustment emphasized by Hicks and Pigou by slow nominal adjustment but did not attribute it to real frictions. Frictions re-appeared in the literature some time later, and only after Phelps (1967) and Friedman (1968) reiterated Hicks's claims that in equilibrium there is some "normal" unemployment, which is independent of nominal factors and which does not induce wage adjustments (see Phelps, 1968, Mortensen, 1970, Holt, 1970a,b, and other contributions to Phelps et al. 1970). The frictions in Phelps's and Mortensen's models were summarized in a łow-of-labor function which depended on the ..rm's relative wage oxer. (Of course, in competitive theory the elasticity of the $\ddagger$ ow-of-labor function to the individual ..rm is in..nite.) The mechanism assumed by Phelps and Mortensen was similar to one of the mechanisms in modern "et ciency wage" theory, and the more recent work of Phelps (1994) recasts that assumption more formally in an equilibrium framework with unemployment (see also Salop, 1979). Holt's papers are more in the tradition of older "structural" analyses (see, e.g. Dow and Dicks-M ireaux, 1958) and like the earlier analyses he assumes a relation between unemployment and job vacancies which implies scale economies in frictional equilibrium.

Early criticisms of the Phelps-M ortensen approach by Rothschild (1973) and others, who demonstrated that the optimizing actions of agents in these models could not support the assumed wage distribution, and also Diamond's (1971) demonstration that in sequential search price will converge to the monopoly price, led to attempts to ..nd reasons for the persistence of wage dixerentials in equilibrium. ${ }^{17}$ Successful user-friendly models with wage distributions for homogeneous labor, however, did not appear in the literature until Burdett and Mortensen's

\footnotetext{
${ }^{17} T$ he equilibrium model of Lucas and Prescott (1974), although innovative, was diф cult to merge with mainstream analysis. The debt that it owes to the ideas in the Phelps volume is obvious, with its island equilibrium and the slow mobility across the islands, but its assumption that each island is in competitive equilibirum is very dixerent from the "non-Walrasian" ideas in the Phelps volume. Both the model and the subsequent empirical implementation by Lilien (1982) inspired a lot of work but eventually the framework used to test Lilien's "sectoral shifts" hypothesis became more akin to search and matching models.
} 
(1998) demonstration that search models with wage posting could support wage distributions when workers search on the job. ${ }^{18} \mathrm{~J}$ ovanovic's (1979) model of jobspeci..c productivity dixerences for ex ante homogenous labor could also be used to derive wage distributions in equilibrium search models. But the main impetus for new theoretical work in search theory came from the realization that there are large łows of jobs and workers in modern labor markets and that search models could shed light on them. ${ }^{19}$

The "matching function" was the key concept in the new generation of models. Although something resembling it was present in several earlier models, ${ }^{20}$ models that used it to simplify the characterization of equilibrium, by doing away with the wage distribution and the explicit modeling of the search decision, ..rst appeared in the literature in the late 1970s. Butters (1977) described a process of the urn-ball type by which sellers let buyers know of their prices by posting advertisements at random in their mailboxes. Hall (1979) used this example to describe how recruiting ..rms select workers out of a homogenous unemployment pool, and derived an explicit functional form for the "job-..nding rate." Pissarides (1979) derived the same functional form and combined it with a general constantreturns-to-scale "job matchings function," to describe the search and matching outcomes. Diamond and Maskin (1979) assumed that meetings in a frictional market are governed by a "search technology," which can be approximated by linear or quadratic functions. Bowden (1980) examined vacancy-unemployment dynamics in search markets by making use of an "engagements" function that is linear-homogenous in the participating vacancies and unemployed workers. Interestingly, he gave as example the Cobb-D ouglas form, with the constant measuring the eq ciency of matching. The equilibrium models that in₹uenced subsequent developments appeared soon after these authors demonstrated the usefulness of the concept of the matching function in capturing the exects of frictions on market

\footnotetext{
${ }^{18}$ P recursors to this model appeared earlier in response to Diamond's (1971) monopoly price demonstration. See Burdett and J udd (1983). More generally, the condition for the existence of a wage distribution is that workers should have access to more than one wage oxer at the same time. See Lang (1991) and M ontgomery (1991) who discuss wage inequality in the context of search models.

${ }^{19}$ For early studies of empirical $\ddagger$ ows see Hall (1972), Feldstein (1973), M arston (1976) and Clark and Summers (1979). Later, the work of Leonard (1987), Dunne et al. (1989), Davis et al (1996), Blanchard and Diamond (1990a) and others provided new stimulus to theoretical developments.

${ }^{20} \mathrm{~N}$ otable early models with something akin to a matching fucntion include the P helps (1968), Mortensen (1970) and Holt (1970b) papers in the Phelps volume, Hansen (1970) and earlier mechanical models of the P hillips and Beveridge curves, such as D ow and Dicks-M ireaux (1958).
} 
outcomes. ${ }^{21}$

\footnotetext{
${ }^{21}$ For surveys of related literature see Mortensen and Pissarides $(1999 a, b)$ on the recent literature on search equilibrium, M ortensen (1986) on models up to 1984 and Devine and K iefer (1991) on early empirical research in the context of search theory.
} 
Table 1: Aggregate matching function studies

\begin{tabular}{|c|c|c|c|c|}
\hline Author & $\begin{array}{l}\text { Country and } \\
\text { coverage }\end{array}$ & $\begin{array}{l}\text { Period and } \\
\text { frequency }\end{array}$ & $\begin{array}{l}\text { Dependent } \\
\text { variable }\end{array}$ & $\begin{array}{c}\text { Job } \\
\text { seekers }\end{array}$ \\
\hline Pissarides (1986) & UK, men & $\begin{array}{l}\text { 1967-1983 } \\
\text { quarterly }\end{array}$ & $\begin{array}{l}\text { male unempl. } \\
\text { outflow rate }\end{array}$ & $\begin{array}{l}\text { unemployed } \\
\text { men }\end{array}$ \\
\hline $\begin{array}{c}\text { Blanchard and } \\
\text { Diamond }(1989,1990 b)\end{array}$ & US & $\begin{array}{l}\text { 1968-1981 } \\
\text { monthly }\end{array}$ & all new hires & $\begin{array}{c}\text { unemployed; } \\
\text { laid-off; } \\
\text { Out of LF; } \\
\text { STU and LTU. }\end{array}$ \\
\hline $\begin{array}{l}\text { Layard, Nickell and } \\
\text { Jackman (1991) }\end{array}$ & Britain & $\begin{array}{c}\text { 1968-1988 } \\
\text { quarterly }\end{array}$ & $\begin{array}{c}\text { unempl. } \\
\text { outflow rate }\end{array}$ & unemployed \\
\hline van Ours (1991) & Netherlands & $\begin{array}{c}\text { 1961-1987 } \\
\text { annual }\end{array}$ & $\begin{array}{l}\text { vacancy } \\
\text { outflow }\end{array}$ & unemployed \\
\hline Burgess (1993) & UK, men & $\begin{array}{l}\text { 1968-1985 } \\
\text { quarterly }\end{array}$ & $\begin{array}{l}\text { male unempl. } \\
\text { outflow rate }\end{array}$ & $\begin{array}{l}\text { male unempl. } \\
\text { rate }\end{array}$ \\
\hline $\begin{array}{c}\text { Burda and } \\
\text { Wyplosz (1994) }\end{array}$ & $\begin{array}{c}\text { France } \\
\text { Germany } \\
\text { Spain } \\
\text { UK }\end{array}$ & $\begin{array}{c}1971-1993 \\
1968-1991 \\
1977-1992 \\
1985-1993 \\
\text { (all monthly) }\end{array}$ & $\begin{array}{l}\text { unemployment } \\
\text { outflow }\end{array}$ & unemployed \\
\hline Warren (1996) & $\begin{array}{c}\text { US } \\
\text { manufacturing }\end{array}$ & $\begin{array}{l}\text { 1969-1973 } \\
\text { monthly }\end{array}$ & all new hires & $\begin{array}{l}\text { unemployed } \\
\text { (from manuf.) }\end{array}$ \\
\hline
\end{tabular}

Feve and

Langot (1996)

France

1971-1989

quarterly

clearpage 
Table 1 (continued): Aggregate matching function studies

\begin{tabular}{|c|c|c|c|c|}
\hline Author & $\begin{array}{c}\text { Country and } \\
\text { coverage }\end{array}$ & $\begin{array}{l}\text { Period and } \\
\text { frequency }\end{array}$ & $\begin{array}{l}\text { Dependent } \\
\text { variable }\end{array}$ & $\begin{array}{c}\text { Job } \\
\text { seekers }\end{array}$ \\
\hline Berman (1997) & Israel & $\begin{array}{l}\text { 1978-1990 } \\
\text { monthly }\end{array}$ & referrals & unemployed \\
\hline Gross (1997) & Germany (West) & $\begin{array}{l}\text { 1972-1994 } \\
\text { quarterly }\end{array}$ & all new hires & unemployed \\
\hline $\begin{array}{c}\text { Gregg and } \\
\text { Petrongolo (1997) }\end{array}$ & Britain & $\begin{array}{l}\text { 1967-1996 } \\
\text { quarterly }\end{array}$ & $\begin{array}{l}\text { unempl. outflow; } \\
\text { vacancy outflow }\end{array}$ & unemployed \\
\hline Bell (1997) & $\begin{array}{c}\text { France } \\
\text { Britain } \\
\text { Spain }\end{array}$ & $\begin{array}{c}1979-1994 \\
1967-1985 \\
1980-1995 \\
\text { (all quarterly) }\end{array}$ & $\begin{array}{c}\text { unempl. outflow } \\
\text { new hires } \\
\text { new hires }\end{array}$ & unemployed \\
\hline $\begin{array}{l}\text { Bleakley and } \\
\text { Fuhrer (1997) }\end{array}$ & US & $\begin{array}{c}\text { 1979-1993 } \\
\text { monthly }\end{array}$ & hires from $U$ & unemployed \\
\hline $\begin{array}{c}\text { Coles and } \\
\text { Smith (1998) }\end{array}$ & Britain & $\begin{array}{l}\text { 1987-1995 } \\
\text { monthly }\end{array}$ & $\begin{array}{c}\text { unempl. outflow } \\
\text { by duration }\end{array}$ & $\begin{array}{l}\text { U stock } \\
\text { U inflow }\end{array}$ \\
\hline $\begin{array}{l}\text { Mumford and } \\
\text { Smith (1999) }\end{array}$ & Australia & $\begin{array}{l}\text { 1980-1991 } \\
\text { quarterly }\end{array}$ & $\begin{array}{l}\text { U outflow rate; } \\
\text { outflow rate } \\
\text { from out of LF }\end{array}$ & $\begin{array}{l}\text { unemployed } \\
\text { (from manuf.) }\end{array}$ \\
\hline Yashiv (2000) & Israel & $\begin{array}{c}1975-1989 \\
\text { monthly }\end{array}$ & all new hires & unemployed \\
\hline
\end{tabular}


Table 2: Sectoral matching function studies

\begin{tabular}{|c|c|c|c|c|c|}
\hline Author & $\begin{array}{c}\text { Country and } \\
\text { coverage }\end{array}$ & $\begin{array}{l}\text { Period and } \\
\text { frequency }\end{array}$ & $\begin{array}{c}\text { Level of } \\
\text { disaggregation }\end{array}$ & $\begin{array}{l}\text { Dependent } \\
\text { variable }\end{array}$ & \\
\hline Burda (1993) & $\begin{array}{l}\text { Czech Rep. } \\
\text { Slovakia }\end{array}$ & $\begin{array}{c}1990-1992 \\
\text { monthly }\end{array}$ & $\begin{array}{l}76 \text { districts } \\
38 \text { districts }\end{array}$ & hires from $U$ & $\mathrm{l}$ \\
\hline $\begin{array}{c}\text { Bennet and } \\
\text { Pinto (1994) }\end{array}$ & Britain, men & $\begin{array}{c}\text { 1967-1983 } \\
\text { quarterly }\end{array}$ & $\begin{array}{l}104 \text { local } \\
\text { districts }\end{array}$ & $\begin{array}{l}\text { unempl. } \\
\text { outflow }\end{array}$ & \\
\hline van Ours (1995) & Netherlands & $\begin{array}{c}\text { 1981-1983 } \\
\text { annual }\end{array}$ & 8 regions & $\begin{array}{l}\text { hires from } \mathrm{U} \text {; } \\
\text { hires from } \mathrm{N}\end{array}$ & $\mathrm{e}$ \\
\hline $\begin{array}{c}\text { Coles and } \\
\text { Smith (1996) }\end{array}$ & $\begin{array}{l}\text { England } \\
\text { and Wales }\end{array}$ & 1987 & 257 TTWAs & $\begin{array}{c}\text { filled } \\
\text { vacancies }\end{array}$ & $\mathbf{l}$ \\
\hline $\begin{array}{c}\text { Boeri and } \\
\text { Burda (1996); } \\
\text { Profit (1997) }\end{array}$ & $\begin{array}{c}\text { Czech } \\
\text { Republic }\end{array}$ & $\begin{array}{l}\text { 1992-1994 } \\
\text { quarterly }\end{array}$ & 76 district & hires from $\mathrm{U}$ & $\mathrm{l}$ \\
\hline $\begin{array}{c}\text { Burda and } \\
\text { Profit (1996) }\end{array}$ & $\begin{array}{c}\text { Czech } \\
\text { Republic }\end{array}$ & $\begin{array}{c}\text { 1990-1994 } \\
\text { monthly }\end{array}$ & 76 district & hires from $U$ & $\mathrm{l}$ \\
\hline $\begin{array}{l}\text { Burgess and } \\
\text { Profit (1998) }\end{array}$ & UK & $\begin{array}{c}1985-1995 \\
\text { monthly }\end{array}$ & 303 TTWAs & $\begin{array}{l}\text { unempl. outflow; } \\
\text { filled vacancies }\end{array}$ & l \\
\hline $\begin{array}{c}\text { Broesma and } \\
\text { Van Ours (1998) }\end{array}$ & Netherlands & $\begin{array}{c}\text { 1988-1994 } \\
\text { quarterly }\end{array}$ & 6 industries & $\begin{array}{l}\text { hires from } \mathrm{U} \text {; } \\
\text { filled vacancies }\end{array}$ & $\begin{array}{l}\text { l } \\
\mathrm{U}+\end{array}$ \\
\hline $\begin{array}{c}\text { Profit and } \\
\text { Sperlich (1998) }\end{array}$ & $\begin{array}{c}\text { Czech } \\
\text { Republic }\end{array}$ & $\begin{array}{c}\text { 1992-1996 } \\
\text { monthly }\end{array}$ & 76 district & hires from $U$ & $S^{\prime}$ \\
\hline $\begin{array}{l}\text { Anderson and } \\
\text { Burgess (2000) }\end{array}$ & US & $\begin{array}{l}\text { 1979-1984 } \\
\text { quarterly }\end{array}$ & $\begin{array}{c}4 \text { states } \diamond \\
20 \text { industries }\end{array}$ & $\begin{array}{l}\text { all new hires; } \\
\text { hires from non-empl; } \\
\text { hires from empl. }\end{array}$ & \\
\hline
\end{tabular}

thispagestyle 



\section{CENTRE FOR ECONOMIC PERFORMANCE Recent Discussion Papers}

469

W. H. Buiter

468 A. S. Litwin

467 P. B. Kenen

466 S. Gomulka

J. Lane

465 F. Green

S. McIntosh

464 J. P. Neary

463 M. Güell

462 W. H. Buiter

461 M. Güell

460 P. Ramezzana

459 H. Lehmann J. Wadsworth

$458 \quad$ R. Griffith

S. Redding

J. Van Reenen

457 J. Swaffield

456 C. Dougherty

455 S. Machin

454 D. Marsden
Monetary Misconceptions

Trade Unions and Industrial Injury in Great Britain

Currency Areas, Policy Domains and the Institutionalization of Fixed Exchange Rates

A Simple Model of the Transformational Recession Under a Limited Mobility Constraint

Working on the Chain Gang? An Examination of Rising Effort Levels in Europe in the 1990s

R\&D in Developing Countries: What Should Governments Do?

Employment Protection and Unemployment in an Efficiency Wage Model

Optimal Currency Areas: Why Does the Exchange Rate Regime Matter?

Fixed-Term Contracts and Unemployment: An Efficiency Wage Analysis

Per Capita Income, Demand for Variety, and International Trade: Linder Reconsidered

Tenures that Shook the World: Worker Turnover in Russia, Poland and Britain

Mapping the Two Faces of R\&D: Productivity Growth in a Panel of OECD Industries

Gender, Motivation, Experience and Wages

Impact of Work Experience and Training in the Current and Previous Occupations on Earnings: Micro Evidence from the National Longitudinal Survey of Youth

Union Decline in Britain

Teachers Before the 'Threshold' 
453 H. Gospel

G. Lockwood

P. Willman

452 D. Metcalf

K. Hansen

A. Charlwood

451 P. Martin

H. Rey

450 P. Martin

H. Rey

449 A. Manning

$448 \quad$ S. Nickell

L. Nunziata

447 W. Buiter

446 R. Portes

H. Rey

445 G. Duranton

D. Puga

444 D. Quah

443 L. Feinstein

442 D. Quah

441 D. Quah

440 E. Mellander

439 F. Green

A. Felstead

D. Gallie
The Right to Know: Disclosure of Information for

Collective Bargaining and Joint Consultation

Unions and the Sword of Justice: Unions and Pay Systems,

Pay Inequality, Pay Discrimination and Low Pay

Financial Integration and Asset Returns

Financial Super-Markets: Size Matters for Asset Trade

Labour Supply, Search and Taxes

Employment Patterns in OECD Countries

The Fallacy of the Fiscal Theory of the Price Level

The Determinants of Cross-Border Equity Flows

Nursery Cities: Urban Diversity, Process Innovation and the Life-Cycle of Products

UK Phillips Curves and Monetary Policy

The Relative Economic Importance of Academic, Psychological and Behavioural Attributes Developed in Childhood

Cross-Country Growth Comparison: Theory to Empirics

Internet Cluster Emergence

The Multi-Dimensional Nature of Labour Demand and Skill-Biased Technical Change

Computers are Even More Important than You Thought: An Analysis of the Changing Skill-Intensity of Jobs 